\title{
POR MI PRECIO O MI BUEN COMPORTAMIENTO: OPORTUNIDADES Y ESTRATEGIAS DE MANUMISIÓN DE LOS ESCLAVOS NEGROS Y MULATOS EN SANTIAGO DE CHILE, $1698-1750^{* *}$
}

El objetivo de este artículo es determinar bajo qué circunstancias los esclavos pudieron optar a la libertad y, también, rastrear sus esfuerzos y estrategias para conseguirla entre 1698 y 1750 , un período en que la esclavitud estaba ampliamente legitimada en Santiago de Chile. Las conclusiones se basan en el análisis de 72 cartas de libertad del Fondo de Escribanos, junto con testamentos de amos y ex esclavos. Con el entrecruzamiento de estas fuentes se demuestra que diversos impedimentos -afectivos, socioeconómicos y legales hereditarios- hicieron de dicha institución una estructura sólida que solo en determinados momentos se hizo flexible. Entonces, los esclavos jugaron un rol activo en su propio proceso de manumisión, negociando un acuerdo mediante el pago de sus precios. Otros, en tanto, debieron intentarlo por el buen comportamiento.

Palabras clave: esclavitud, manumisión, cartas de libertad, negros, mulatos, pardos libres, esclavos.

The aim of this paper is to determine under what circumstances slaves became eligible for freedom and to track their efforts and strategies to achieve it between 1698 and 1750 . This is a period when slavery was widely legitimized in Santiago, Chile. The findings are based on the analysis of seventy two letters of freedom, along with wills written by masters and former slaves. After the crossed analysis of these primary sources the author argues that various emotional, socio-economic and legal impediments gave shape to a rigid institution that allowed a minimum flexibility to obtain liberty. Thus, slaves played an active role in their own manumission processes, negotiating agreements through payment for their freedom or opting for the strategy of manumission trough good behavior.

Key words: slavery, manumission, letters of freedom, blacks, mulattoes, free pardos, slaves.

Fecha de recepción: octubre 2008

Fecha de aceptación: marzo 2009

* Licenciado en Historia, Universidad Andrés Bello; candidato a Magíster, Universidad de Chile.Correo electrónico: cm.ogass.bilbao@gmail.com

** Agradezco a los miembros del Seminario Permanente "Esclavos y Castas en América" de la Universidad de Chile por sus valiosas y apasionadas críticas y, especialmente, a su directora, la profesora Celia Cussen. 


\title{
INTRODUCCIÓN
}

\author{
Aman y codician naturalmente todas las criaturas \\ del mundo la libertad, cuanto más los hombres que \\ tienen entendimiento sobre los otros y mayormente \\ en aquellos que son de noble corazón ${ }^{1}$
}

La vida de Juan Esteban de Chandía e Isabel de Fuica transcurría con tranquilidad en la ciudad de La Serena. Ambos, marido y mujer legítimos, vivían con la comodidad a la que acostumbraban las personas de la élite local. Pero la calma que hacía honor al nombre de la urbe se vio trastocada, momentáneamente, con el arribo de una carta. La misiva llegó con los primeros días de octubre de 1703, proveniente del monasterio de monjas de San José del Carmen en Santiago. Su destinatario, al tomar el sobre con sus manos y dirigir sus ojos al remitente, se habría sorprendido al ver escrito el nombre de alguien a quien creía olvidado. Era Mateo de Fuica: un mulato esclavo que, años atrás, había nacido en su casa.

Hacía 10 meses que Mateo de Fuica prodigaba sus servicios en dicho monasterio. El 31 de diciembre de 1702, sus amos serenenses lo habían legado al recinto religioso a modo de obra pía. Así, al momento de morir ambos, sus almas tendrían un viaje más placentero hacia el tribunal del juicio final y Dios, seguramente, rebajaría sus penas en el Purgatorio. Pero en el protocolo que sancionó jurídicamente ese acto se había estampado, con tinta, una cláusula que le incomodaba: "se prohíba que la dicha madre priora ni su síndico pudiesen enajenar dicho esclavo ni darle libertad con cláusula expresa de que si lo tal obrasen fuese en ninguna la dicha donación [...] porque la hacían con calidad de que sirviese a dicho monasterio perpetuamente"2.

Diez meses fueron suficientes para que Mateo se percatase de que sus labores en el claustro eclesiástico no le acomodaban ni, menos, el perpetuo cautiverio al que había sido destinado. Su esposa, María Pizarro, una parda libre ${ }^{3}$-mulata que consiguió su libertad con anterioridad- trabajaba en la ciudad de Santiago. Con sus constantes asientos ${ }^{4}$ no solo logró ahorrar diariamente el dinero para la libertad de

1 Cuarta Partida, Título XXII.

2 Carta de libertad a Mateo de Fuica, Santiago, 8 de febrero, 1704, Archivo Nacional de Chile, Escribanos de Santiago (en adelante ANCH, ES), volumen 458, f. 265.

3 El término "pardo libre", usado por diferentes escribanos de Santiago, es discrecional, confuso y esconde una doble realidad con significados antagónicos. La denominación alude a mulatos libertos y, también, a sus hijos, pues tiene un carácter hereditario. Así, designa a ex esclavos con un color de piel intermedio entre el blanco y el negro que consiguieron su libertad y, también, a mulatos que nacieron disociados de la experiencia de la esclavitud, pero que comparten la misma pigmentación de piel y la condición jurídica de sus progenitores.

El asiento es una modalidad de contrato laboral en que el otorgante se compromete a prestar distintos servicios, ya sea domésticos o agrícolas. A cambio, el contratista, además del pago de un sueldo mensual, asume la responsabilidad del mantenimiento de vestuario, alimentación y salud. 
su esposo, sino que fue creando lazos y vínculos con hombres y mujeres de la élite y, asimismo, con personas de su mismo color o con tonalidades más oscuras que, en caso de emergencia, podrían transformarse en eventuales prestamistas. Porque la sociedad de la capital del Reino de Chile, al igual que la del resto de las ciudades hispanoamericanas indianas, fue policromática y multiétnica. De las cerca de 12 mil personas que la habitaban a comienzos del siglo XVIII, entre el 20 y el $26 \%$ era negra, mulata o zamba, ya fuesen libres, libertos o esclavos ${ }^{5}$.

Con el dinero en mano, María Pizarro y Mateo de Fuica fueron a negociar su libertad. La confianza que el mulato se granjeó trabajando con esfuerzo y obedeciendo cada una de las órdenes o caprichos de las monjas facilitó los canales de comunicación. La madre priora Francisca Teresa del Niño Jesús y el síndico Francisco Díaz Pimienta no pusieron obstáculo cuando vieron los 600 pesos que le otorgarían los mulatos. En el siglo XVIII esa cantidad era altísima, más considerando que una oveja costaba 4 reales, una mula 4 pesos y un caballo 60 . Su precio alcanzaba para implementar, fácilmente, una granja. Pero había que convencer a los amos. Era el último paso. Y el primordial para que su estrategia rindiera dividendos.

Eso motivó a Mateo a enviar la correspondencia a La Serena. Tuvo que extremar sus esfuerzos retóricos y, quizás, habría contado con la ayuda de la madre priora. Su carta, lamentablemente, el Archivo Nacional la ha querido callar. O más bien la modorra del escribano, quien no quiso copiarla y solo se refirió a ella con un: "aquí la carta que está en foja 17" . Pero sí se conservó la respuesta de su amo:

“en este ínterin hemos tenido muchos ruegos del dicho mulato pidiéndonos perdón de lo pasado poniendo a Dios y a su Santísima Madre por intercesores reconviniéndonos con la crianza y el amor que le tuvimos y todo se reduce a que seamos intercesores con Vuestra merced y las santas madres para que le permitan libertarse prometiendo dará su valor en plata o un negro en su lugar al monasterio y supuesto que no se dedica a servirlo con afecto y voluntad como era nuestro deseo le suplicamos entre ambos a Vuestra merced y a nuestra madre priora le conceda la súplica que nos mueve"7.

El discurso argumentativo de Mateo fue contundente: apeló al recuerdo amoroso de sus amos que lo criaron y, también, hizo profesión de buen cristiano al pedir la intercesión de Dios y la Virgen María. Incluso, ante cualquier actitud que pudie-

5 Armando de Ramón, Santiago de Chile. Historia de una sociedad urbana. 1541-1991, Santiago, Editorial Sudamericana, 2000, 80, revisó las partidas de bautismo de la Parroquia del Sagrario, que comprendía el centro de la ciudad, entre 1691 y 1695: de ellas, $56 \%$ eran españolas; $14 \%$ indígenas y el 28,5\% de negros y sus mezclas. Jean Paul Zúñiga, "Morena me llaman... Exclusión e integración de los afroamericanos en Hispanoamérica: el ejemplo de algunas regiones del antiguo virreinato del Perú (siglos XVI-XVIII)", en Berta Ares Queija y Alessandro Stella (coords.), Negros, mulatos y zambaigos: derroteros africanos en el mundo ibérico, Sevilla, Consejo Superior de Investigaciones Científicas, 2000, 116, revisó 1.154 partidas bautismales en las Parroquias del Sagrario y de Santa Ana entre 1641 y 1663: de ellas, 33\% eran españolas; $24 \%$ indígenas y $26 \%$ mulatos, negros y zambos. Marcelo Carmagnani y Herbert Klein, "Demografía histórica: La población del Obispado de Santiago. 17771778", en Boletín de la Academia Chilena de Historia XXXII: 72, Santiago, 1965: en este registro, los resultados son $53 \%$ españoles; $14,6 \%$ mestizos; $13,3 \%$ indios; $15,2 \%$ mulatos y $3,6 \%$ negros.

6 ANCH, ES, volumen 458, f. 265 vta.

7 Ibid., fs. 267-267 vta. Las cursivas son nuestras. 
se ser percibida como irrespetuosa o soberbia -discordante con el lugar al que lo relegó la jerarquía-, el mulato les pedía perdón. Es que "los gestos de la insubordinación no eran nimios por pequeños que fueran. Todo el cuerpo debía ser sumiso y respetuoso"8. Así, el 8 de febrero de 1703, la madre y el síndico lo liberaban: "por cuanto tiene recibidos seiscientos pesos de a ocho reales que les dio y pagó María Pizarro mujer legítima del dicho Mateo Fuica" ${ }^{9}$. Marido y mujer, producto de una negociación con su amo, le doblaban la mano a un destino que lo condenaba a permanecer como esclavo desde el nacimiento hasta su muerte.

Tal como las de esta pareja, el siguiente artículo analiza las oportunidades y estrategias de manumisión de los esclavos negros y mulatos de Santiago de Chile entre 1698 y 1750 . Sus planteamientos y conclusiones se basan en el estudio de 72 cartas de libertad o ahorramiento encontradas, aleatoriamente, en 50 tomos del Fondo de Escribanos de Santiago en dicho periodo. En ellas, 83 esclavos consiguieron su libertad inmediata o condicionalmente. Para una mejor comprensión de este proceso, se suman juicios de la Real Audiencia y testamentos de los amos y ex esclavos.

A diferencia de lo que ocurre con la historiografía chilena, los estudios sobre la manumisión en América Latina han mantenido un desarrollo constante en las últimas décadas ${ }^{10}$. Desde 1970, sobre la base del análisis cuantitativo, varios historiadores han demostrado el valor de las cartas de libertad como fuentes para caracterizar a la población de amos y esclavos que participaron en el proceso ${ }^{11}$. Aprovechando que su estructura protocolar no manifiesta variaciones geográficas profundas, el siguiente paso fue comparar las distintas realidades hispanoamericanas para sondear el grado de permeabilidad de los distintos regímenes. Hay consenso entre ellos que el acceso a la libertad en América Latina -en comparación con Estados Unidos- fue relativamente más fácil y estaba ampliamente extendido. Más aún, se trató, esencialmente, de un fenómeno urbano.

Desde 1990 Carlos Aguirre y Christine Hünefeldt han analizado la manumisión en Lima. Utilizando archivos judiciales y protocolos notariales -cartas de libertad,

8 Alejandra Araya, "Sirvientes contra amos: las heridas en lo íntimo propio", en Rafael Sagredo y Cristián Gazmuri (coords.), Historia de la vida privada en Chile, Vol. I: El Chile tradicional. De la Conquista a 1840, Santiago, Taurus-Aguilar Chilena de Ediciones, 2005, 180.

9 ANCH, ES, volumen 458, f. 265.

10 En Chile existen estudios sobre la libertad de los esclavos, pero no con el ritmo de producción de otros países latinoamericanos. Carolina González, "En busca de la libertad: la petición judicial como estrategia política. El caso de las esclavas negras (1750-1823)", en Tomás Cornejo y Carolina González (coords.), Justicia, Poder y Sociedad en Chile: recorridos históricos, Santiago, Ediciones Universidad Diego Portales, 2007, 57-83. En él, la autora analiza el discurso de las esclavas en el sistema judicial como una forma de "narrativa de la resistencia esclava", para oponerse al sistema de dominación esclavista, analizando sus estrategias para alcanzar la reunión familiar y demandar los abusos cotidianos por sevicia.

11 Stuart Schwartz, "The manumission of slaves in colonial Brazil: Bahia, 1684-1745", en The Hispanic American Historical Review 54:4, Durham, 1974, 603-635. James Kiernan, "Baptism and manumission in Paraty", en Social Science History 3:1, Durham, Autumn, 1978, 56-71. Lyman Johnson, "Manumission in colonial Buenos Aires, 1776-1810", en The Hispanic American Historical Review 59:2, Durham, 1974, 258-279. Frederick Bowser, "The Free persons of color in Mexico City and Lima: Manumission and Oportunity, 1580-1650", en Stanley Engerman y Eugene Genovese (coords.), Race and Slavery in the Western Hemisphere: Quantitative Estudies, Princeton, Princeton University Press, 1975, 331-367. 
solicitudes de papel de venta y alegatos por sevicia-, ambos han demostrado el activo rol que cumplieron los esclavos de comienzos del siglo XIX para ir, gradualmente, apropiándose de pequeñas cuotas de autonomía ${ }^{12}$. Sus embates, no virulentos, públicos ni abiertos, fueron desgastando y erosionando la estructura esclavista, contribuyendo a su abolición. En este sentido, fueron agentes de su propio destino: sujetos que, a pesar de las condiciones adversas en que vivían, "pudieron ejercer un impacto no solo sobre su destino individual, sino también sobre la sociedad entera y sobre las formas en que se ejercía la dominación"13. En el contexto político y económico de Lima de comienzos del siglo XIX, no obstante, la esclavitud, como sistema de producción, estaba en una fase gradual de decadencia y pérdida de legitimidad por parte de algunos sectores liberales.

La manumisión del mulato Mateo -antes descrita- no ocurrió en un contexto similar. La esclavitud en Santiago entre 1698 y 1750 estaba completamente legitimada y, además, los altos precios dificultaban la compra de la libertad. Pero su caso no tiene un valor meramente anecdótico, pues ilustra uno de los mecanismos recurrentes que utilizaron los esclavos para abandonar su condición. La servidumbre -como una relación social entre el amo y el esclavo- fue una institución absolutamente jerárquica, con disímiles grados de poder y en la cual la idea de la subordinación estaba impuesta y normalizada. Pero, si bien su condición les quitó el dominio sobre muchos aspectos de su vida física y mental, nunca pudo penetrar ni normar un aspecto insoslayable sobre su propia personalidad: el debate psicológico interno sobre cómo mejorar su condición humana.

Sin embargo, la manumisión de Mateo tampoco es arquetípica. El análisis individualizado de las cartas de libertad nos revela que hay una diversidad de caminos recorridos por hombres y mujeres; negros y mulatos; adultos y párvulos; familias e individuos para conseguir la libertad, aunque, obviamente, se puedan establecer generalidades. Incluso, cada caso es extremadamente rico por su particularidad y es difícil encasillarlos en clasificaciones estáticas. Es que -tal como plantea Rebecca Scott para los esclavos de Cuba- las respuestas a la esclavitud en las sociedades hispanoamericanas fueron extremadamente complejas y variopintas, rebasando, por mucho, la dicotomía entre resistencia y adaptación ${ }^{14}$.

¿Acaso todos los esclavos buscaron, enérgicamente, la libertad? ¿Qué significado le dieron a ese término, en una sociedad en que ni el romanticismo ni la revolución francesa le otorgaban, aún, un carácter universal e intrínseco al ser humano y, además, donde la mayor parte de la población estaba sometida y subordinada, en una enmarañada red de jerarquías? Seguramente, uno bastante más restringido del que conocemos y manejamos en la actualidad. Al introducirnos en la complejidad de su significado, advertimos que las motivaciones de los esclavos

12 Carlos Aguirre, Agentes de su propia libertad: los esclavos de Lima y la desintegración de la esclavitud. 1821-1854, Lima, Pontificia Universidad Católica del Perú, 1995. Christine Hünefeldt, Paying the price of freedom. Family and labor among Lima's slaves. 1800-1854, California, University of California Press, 1994.

13 Aguirre, op. cit., 20.

14 Rebeca Scott, Slave Emancipation in Cuba. The transition to Free Labor. 1860-1899, Princeton, Princeton University Press, 1985, 6. 
para conseguirla pudieron ser más variadas y harto más intrincadas de lo que pudiéramos prejuzgar. Nuestra intención no es solucionar este difícil asunto, sino ocuparnos de un pequeñísimo grupo: los exitosos, aquellos cuyas estrategias rindieron dividendos.

Para la legislación alfonsina, la esclavitud fue una institución ignominiosa, porque el hombre "que es la más noble y libre criatura, entre todas las otras criaturas que Dios hizo, se torna por ella en poder de otro" 15 . Y era vejatoria, ya que no solo no se podía disponer de los bienes, sino "de su persona misma no es poderoso" 16 . Aun así, se consideraba como una etapa transitoria que nunca decreció la condición de "persona" de quien la sufriese. Por lo mismo, la libertad era una opción que vendría a redimir ese estado "contra razón de natura"17. Pero, "así como la servidumbre es la más vil cosa de este mundo (que pecado no sea) y la más despreciada, así la libertad es la más cara y la más preciada"18. A pesar del valor que le concedieron, no existió ninguna normativa legal que constriñese a los amos a manumitir a los esclavos. Era una prerrogativa patronal y absolutamente discrecional.

Existe consenso historiográfico en que los cuerpos legales -como idealizaciones expectantes del comportamiento humano- no son útiles para comprender cabalmente la realidad. Muchas veces las prácticas sociales de la cotidianidad sobrepasan y/o atentan contra ella. Y esto es más cierto en una sociedad donde la legalidad era casuística. Las Siete Partidas, no obstante, definieron dos formas consuetudinarias en que se concedía la libertad y que, por lo visto, se transportaron a las sociedades hispanoamericanas. "Señores, y hay algunos, que aforran sus siervos, tan solamente por su buena voluntad, queriéndoles hacer bien y merced, no tomando precio ninguno de ellos. Y otros que los forran por precio que reciben" 19 .

Pero la libertad no siempre fue un estado seguro. Y esto fue así

"porque el hombre que da algo a otro, lo puede después revocar, así como dijimos en el Titulo de las donaciones, en la Quinta Partida de este libro [...] Mas si el precio que hubiese recibido por aforrar no lo hubiese dado el aforrado por sí, mas otro alguno por el; o si lo hubiese aforrado por mandado de otro, que era su señor; entonces, decimos que aquel que lo hubiese hecho así libre, no lo podría tornar así en servidumbre"20.

Si la libertad era concedida "de buena voluntad", entonces, se homologaba a la clasificación jurídica de la donación que mermaba el patrimonio de quien la concedía. Y, por lo tanto, podía ser revocada. No así cuando los esclavos cancelaban por ella.

De acuerdo a lo anterior, se esbozan, a priori, dos estrategias de los esclavos para obtener su manumisión: pagar por su precio o adoptar un buen comportamiento, lo que significaba fidelidad, obediencia, cristiandad y sumisión a la espera de

\footnotetext{
15 Cuarta Partida, Título V.

16 Idem.

Ibid., Título XXI

Ibid., Título XXII, Ley VIII.

Ibid., Título XXII, Ley IX.

20 Idem.
} 
que la psicología del amo se inclinase a percibirlos menos como objetos y más como sujetos. La primera, aunque nunca fácil ni automática, era jurídicamente segura, mientras que la segunda, bastante inestable. Porque, en cuanto bienes, muchos amos prefirieron venderlos, heredarlos, donarlos o hipotecarlos, anulando su estrategia afectiva a largo plazo. En este sentido, la manumisión remuneratoria se puede interpretar como una vía de autentificar legalmente la libertad y, conjuntamente, de apresurar un proceso natural que podía concluir de forma exitosa, eventualmente, tras largos años de una espera paciente y mansa.

En concordancia con lo anterior, nuestro objetivo principal está en determinar las oportunidades más propicias en que los esclavos pudieron optar por la manumisión en Santiago. En definitiva, sondear cuándo, cómo y bajo qué circunstancias específicas la libertad no fue una quimera y, también, rastrear los esfuerzos y estrategias que desplegaron para conseguirla, incluyendo en el análisis un aspecto que ha sido soslayado por la historiografía: el régimen patrimonial hereditario indiano, que operó como una barrera más a sus opciones. Abordando en profundidad este fenómeno, podemos conocer un fragmento de la historia de la esclavitud negra, una dimensión social y cotidiana de un sistema económico mundial que se extendió en el reino de Chile, un territorio marginal, durante cerca de 300 años ${ }^{21}$.

Sin embargo, cualquiera que hubiese sido la ruta escogida para conseguirla, la manumisión fue, generalmente, un proceso y se obtuvo mediante un acuerdo (o negociación) en que se mezclaron intereses económicos y afectivos. Se expresó, así, cierta refinada racionalidad por parte de los esclavos para manipular las variables de su entorno. También, la probabilidad de ser libres aumentó cuando los esclavos tenían nexos familiares. La familia fue -como expresa Hünefeldt para Lima- "el cuerpo sobre el cual giró la vida de los esclavos y la unidad combativa por medio de la cual pudieron lograr la libertad"22.

Finalmente, este estudio suscribe la postura de Carlos Aguirre, en cuanto percibimos y presentamos a los esclavos como sujetos históricos y absolutamente activos. El alcance de esta visión implica superar dos imágenes frecuentes y erróneas:

"por un lado, aquella que les atribuyó mucho tiempo la condición de víctimas pasivas (y hasta conformes) del sistema de dominación; por otro lado, la imagen romántica de

21 Philip D. Curtin, The Atlantic slave trade: A census, Madison, Wisconsin, The University of Wisconsin Press, 1969, 18. Según sus cálculos, en el periodo de intensificación de la trata, entre 1701 y 1810, la importación de esclavos africanos a América -incluyendo las colonias españolas, portuguesas, francesas, inglesas y danesas- habría alcanzado la cantidad de 6.051.700. Entre 1492 y 1870 la América hispana recibió 1.552.000 esclavos. De acuerdo a su distribución geográfica, el reino de Chile ocupó un lugar marginal, alcanzando la cifra de 6.000 piezas. No obstante, el mismo autor se encarga de ponderar sus cifras: "Uno de los peligros de exponer cifras es hallarlas luego citadas con un grado de certidumbre que nunca se les atribuyó. Esto es particularmente cierto cuando los porcentajes se calculan con una aproximación del orden de las décimas de por ciento, pero el rango de error de las cifras absolutas puede ascender hasta el $20 \%$. Afirmemos, entonces, desde el principio, que la mayoría de las cantidades ofrecidas a continuación son imprecisas. No se ha intentado dar valores exactos sino aproximaciones donde una cifra que está dentro de un rango de error del $20 \%$ se estima que es una respuesta correcta; es decir, un resultado satisfactorio dada la calidad de los datos procesados".

22 Hünefeldt, op . cit., 5. La traducción es nuestra. 
quienes han visto en el esclavo un rebelde permanente, siempre dispuesto a enfrentarse al amo y luchar por su libertad: el mito del esclavo indomable. Ambas visiones (ideológicas) son ciertamente unilaterales y carecen de los matices necesarios que una apreciación más cercana de los hechos debería percibir" 23 .

SANTIAGO: ECONOMÍA, SOCIEDAD Y NOCIÓN DE LIBERTAD ENTRE 1698 Y 1750

\section{Del océano a la ciudad: el mercado de precios y la extensión social de la esclavitud}

Hasta mediados del siglo XVII, Santiago fue una ciudad que, comparada al resto de las urbes hispanoamericanas, era pequeña en magnitud y, más bien, tenía el aspecto de una aldea: los límites entre lo rural y lo urbano eran difusos. Bordeando el cuadrilátero de la Plaza de Armas, su corazón y pulso, sus casas más lujosas eran monocromáticas y solo lucían el blanco de la cal. Los callejones se hallaban polvorientos y sus calles sin pavimentación. Poco ruidosa, por la escasa población: cerca de doce mil habitantes repartidos entre el centro y su periferia. Era pobre y de un aspecto rústico. Pero el terremoto del Perú, en 1687, y la peste de polvillo negro que cubrió los trigales, obligaron a los limeños a buscar al sur lo que comenzó a escasear en su propia tierra. El intercambio entre el virreinato y la capitanía se agilizó desde entonces, animando a la zona ubicada entre el Choapa y el Maule, especialmente, a la producción del trigo ${ }^{24}$. El grueso de la exportación del valle central salió por Valparaíso, lugar que fue, además, la salida del excedente que entregaba el fértil valle de Aconcagua. En el puerto, los granos se depositaron en las antiguas bodegas y reemplazaron, paulatinamente, al sebo, que comenzaría a relegar su otrora condición de principal producto de exportación.

Medianamente cerca de Valparaíso, su ubicación privilegiada convirtió a Santiago en un nexo comercial obligado entre los extremos sur y norte de la capitanía general. La incipiente actividad económica propició el tránsito paulatino a una ciudad relativamente próspera: Santiago, lentamente, comenzaba a consolidarse como el centro político y económico del reino de Chile ${ }^{25}$. El impulso estimulado por las exportaciones, encabezado por los mercaderes, contagió a diversos sectores. Pero no todo fue causal de alegrías. Los esclavos -otro producto del comercio con el virreinato del Perú- aún no eran lo suficientemente numerosos para suplir el trabajo de los indígenas de la encomienda, una institución que agudizaba su fase de decadencia ${ }^{26}$. Los lamentos fueron expuestos por López de Gamboa, procurador del Cabildo, en una sesión de 1705:

23 Aguirre, op. cit., 20.

24 Sergio Villalobos, Historia de Chile. Tomo II, Santiago, Editorial Universitaria, 2004, 157-160. Rolando Mellafe, Historia Social de Chile y América, Santiago, Editorial Universitaria, 2004, 275.

25 De Ramón, op . cit., 89-93.

26 Rolando Mellafe, La introducción de la esclavitud negra en Chile. Tráfico y rutas, Santiago, Estudios de Historia Económica Americana de la Universidad de Chile, 1959, 107-113. Mario Góngora, Encomenderos y estancieros. Estudios acerca de la constitución social aristocrática de Chile después de la Conquista, 1580-1660, Santiago, Departamento de Historia de la Universidad de Chile, 1970, 41-47. 
"Aunque pudieran pasar a estas provincias negros de Portobelo, como es tan larga distancia y tan dilatadas las navegaciones y los costos tan abultados, cuando algunos arriban a esta ciudad, tienen precios tan excesivos que se venden por setecientos y ochocientos pesos, y no hay caudal para poderlos comprar" 27 .

Así, un grupo de la sociedad abogó por la entrada de un mayor número: única forma de acceder a ellos y, conjuntamente, abaratar sus precios.

En 1702 -tres años antes de la queja de López-, la Corona había concedido el monopolio del tráfico negrero hacia las Indias a la Compañía Real de Guinea, administrada por los franceses ${ }^{28}$. La medida se debía a la llegada de una nueva dinastía al poder peninsular: Felipe V de Borbón. La concesión le obligaba internar: “48.000 piezas de Indias de ambos sexos, y de todas edades, en 4.800 cada uno de los dichos diez años" 29 . De ellos, solo entre 500 y 600 podían desembarcar en el puerto de la Santísima Trinidad de la ciudad de Buenos Aires. Pero, para desdicha del grupo esclavista de Santiago, ninguna pieza podía cruzar la cordillera. Aunque Rolando Mellafe constató que desde el siglo XVII entraron esclavos por la ruta atlántica -y la medida fue tolerada por la Corona-, la oferta no fue suficiente para propiciar una devaluación general de los precios ${ }^{30}$. El cabildo, exasperado, solicitó al Rey que reconsiderara su medida. De ello dependía "el mayor lucimiento y alivio de los vasallos de Su Magestad", pues "cuanto había descaecido este Reino por falta de servicios, tanto tendría de aumento con el libre comercio de los negros" 31 .

Se combinaron, así, los argumentos económicos con los sociales. Es que, para los amos, la esclavitud en Santiago fue, además, una forma de hacer ostentación pública de su poder adquisitivo y su capacidad de disciplinar a los esclavos. A pesar de que los precios eran altísimos, el tráfico de esclavos desde Lima era asiduo y el "ecúmenos del negro" se extendió por la mayor parte del territorio ${ }^{32}$. Celia Cussen analizó la proporción de esclavos en el reino de Chile, basándose en el censo de 1778: "En la zona de Coquimbo más del 20\% de la población se componía de negros y mulatos; en Santiago la cifra era algo mayor al 18\%, mientras que en las zonas al sur de la capital, como Colchagua y Maule, la cifra bajaba alrededor del 8\%"33. Así, un grupo importante se quedó en Santiago y otro se fue a trabajar en las haciendas de Chile central o las minas del norte del reino.

La mayoría de los esclavos que provenían de la Ciudad de los Reyes eran negros que venían directamente de África ${ }^{34}$. Eran de casta congo, angola, arará o

27 Gonzalo Vial Correa, El africano en el Reino de Chile. Ensayo histórico-jurídico, Santiago, Instituto de Investigaciones Históricas de la Universidad Católica de Chile, 1957, 48.

28 Elena F. S. de Studer, La trata de negros en el Río de la Plata durante el siglo XVIII, Buenos Aires, Instituto de Historia de la Universidad de Buenos Aires, 1958, 60.

29 Ibid., 105.

30 Mellafe, La introducción de la esclavitud..., op. cit., 240-246.

31 Vial, op . cit., 79

32 Mellafe, La introducción de la esclavitud..., op. cit., 102-106.

33 Celia Cussen, "El paso de los negros por la historia de Chile", en Cuadernos de Historia de la Universidad de Chile 25, Santiago, 2006, 53.

34 De 24 cartas de compra-venta del tomo III de Escribanos de Valparaíso, que cubre algunas de las transacciones realizadas entre 1700-1705 estas son las proporciones: 18 negros (75\%); 4 mulatos $(16,6 \%)$; y dos zambos $(8,8 \%)$. 
popo. Su condición de no bautizados se señalaba con el rótulo de "costal de huesos y con alma en boca". Otros, en cambio, habían nacido en las Indias y se les llamaba criollos. Estos últimos eran ladinos: conocían la lengua castellana y tenían una condición más elevada que los bozales de África, pues se habían iniciado en el evangelio de Jesucristo. Los precios eran diversos, pero altos: hasta 900 pesos. Los elevados valores se explican por los almojarifazgos (una especie de arancel aduanero) que debían pagar en Cartagena, Portobelo, Guayaquil y Lima; y, también, por el recargo discrecional que hacía el asentista y apoderado, pues que llegase uno vivo era toda una travesía oceánica.

Las quejas de los vecinos de Santiago no eran exageradas, como otras de las muchas peticiones paralelas que elevaron al rey en esa época. Aburridos de esta situación, continuaron con su campaña de libre tráfico negrero, pero nunca imaginaron que un suceso que ocurría al otro lado del Atlántico posibilitaría la concreción de sus demandas: el triunfo de Gran Bretaña en la guerra de sucesión por el trono español. Por la Paz de Utrecht, se permitió a los ingleses controlar el tráfico en el puerto de Buenos Aires, mediante un Real Asiento de Negros. Desde el año 1713 se elevó a 1.200 la cifra de africanos destinados a ese puerto y se autorizó que se condujeran 400 hacia Chile. Los vecinos esclavistas de Santiago habían concretado, después de 12 años, sus antiguas aspiraciones. Gonzalo Vial detalló algunas de sus repercusiones en el precio de los esclavos. Según él, su valor decreció en cerca de un 30 o $50 \%$ y "alcanzaron un valor medio de 290 a 310 pesos, cada varón; y 330 y 360 pesos, cada hembra" 35 .

Las cifras revelan un aspecto interesante. La mujer equipara y, también, excede el precio del varón. Esto se entiende porque la demanda de esclavos se hizo principalmente para el servicio doméstico en Santiago, lo que, considerando la cultura de género imperante en la época, implicaba tareas preferentemente femeninas. También, al no existir una fuerte y expedita conexión con el mercado externo -el reino de Chile no fue nunca un punto de tráfico directo-, los amos habrían precavido las eventuales intermitentes ofertas, utilizando la continua capacidad reproductiva de las entrañas femeninas para abastecer la creciente demanda. Porque la esclavitud fue una condición que se heredó desde el vientre materno.

La devaluación también produjo un cambio en el patrón de propiedad de esclavos. La historiografía tradicional postula que, comparado con las economías de plantación de Brasil o Cuba, en Santiago no existió una gran concentración de esclavos. Los lotes fluctuaban entre 20 a 30 piezas en las familias de estratos altos y los únicos que lograron tener una extensa cantidad fueron los jesuitas: 1.200 esclavos en el valle central ${ }^{36}$. Por lo mismo, "dentro de esta lejana y pequeña sociedad tener sirvientes de color pasó a ser un privilegio determinante del prestigio social de la familia; un lujo, una preocupación social exclusiva de peninsulares y criollos"37.

35 Vial, op. cit., 49

36 Diego Barros Arana, Un decenio de la Historia de Chile, Santiago, Imprenta Barcelona, 1973.

37 Macarena Ponce de León, "Vida de los esclavos en Chile. 1750-1800", en Julio Retamal (coord.), Estudios Coloniales III, Santiago, Centro de Estudios Coloniales de la Universidad Andrés Bello, 2004, 240-241. 
No obstante, la baja paulatina de precios produjo interesantes cambios en el acceso a la mano de obra esclava. Y no fue raro que algunos ex esclavos participaran en la compra y venta. En 1734 la parda libre María Negrón vendía: "una negra nombrada María Antonia"38. El mismo año, Margarita Pozo, también parda libre, vendía a don Basilio, "una mulata mi esclava nombrada Rosa que será de edad de diez y ocho a diez y nueve años criada y nacida en mi casa hija de Lorenza Díaz mi esclava" 39 . Incluso, en algunos testamentos de pardos libres es corriente encontrar la posesión de algunos esclavos. Luis de Orta, pardo libre, mencionaba: "por mis bienes una negra nombrada María Josefa, y un negro nombrado Santiago" 40 . Y Antonia de la Carrera, parda libre, detalló la posesión de cinco esclavos, que fueron entregados a sus hijas en forma de dote ${ }^{41}$.

Si fuera nuestro interés, estos datos nos proporcionarían una suculenta información para elucubrar algunas hipótesis sobre las motivaciones de la manumisión. Sin embargo, para el objetivo de este estudio, solo queremos demostrar el alto grado de legitimidad que tenía la esclavitud en todos los estratos sociales, incluso en los más bajos, y además, el hecho de que en Santiago existieron diversos tipos de propietarios: grandes, medianos y pequeños. Establecer una radiografía de esta tendencia es imposible, porque no existe ningún padrón de la propiedad de esclavos para esa fecha, como sí ocurre en otras ciudades hispanoamericanas indianas. ¿En qué condiciones y con qué herramientas pudieron permear los esclavos un sistema tan extendido y legitimado en la sociedad?

La esclavitud urbana y doméstica: los esclavos entran y salen de la casa

"El aire de la ciudad da la libertad"42.

Un proverbio alemán -Die Stadtluft mach frei- anunciaba el nuevo espíritu de un sector de la población, originado junto con el renacimiento de las ciudades en la Europa cristiana desde los siglos XI al XIII. Con él, se aludía al nuevo estatus jurídico que alcanzaron los campesinos, antiguos siervos de la gleba, al abandonar los campos y asentarse en los incipientes burgos que se desperdigaron por el territorio. Lejos de los señores y en un incipiente contexto urbano, los otrora vasallos fueron conquistando su independencia y autonomía. Varios siglos más tarde, y en una nueva geografía, la estructura arquitectónica e institucional de la ciudad hispanoamericana fue el escenario más propicio en que los esclavos encontraron algunas herramientas para conseguir su libertad. Pero, obviamente, en condiciones más precarias y más difíciles.

38 Venta de María Negrón, parda libre. Santiago, 23 de noviembre, 1734, ANCH, ES, volumen 632 , f. 278 .

39 Venta de Margarita del Pozo, parda libre. Santiago, 9 de diciembre, 1734, ibid., f. 285.

40 Testamento de Luis de Orta, pardo libre. Santiago, 8 de junio, 1741, ibid., volumen 635, f. 349 vta.

41 Testamento de Antonia de la Carrera, parda libre. Santiago, 28 de noviembre, 1755, ibid., volumen 601 , f. 115 .

42 Henri Pirenne, Historia económica y social de la Edad Media, México, Fondo de Cultura Económica, 1970, 44 
Para Christine Hünefeldt, en el caso de los esclavos de Lima, "el elemento que más definió sus vidas fue la ciudad y todo lo que ello implicó" 43 . El crecimiento demográfico y comercial de las urbes trajo aparejado el aumento de la población esclava, pues se necesitaba de mano de obra que supliera los servicios. La vida cotidiana sin ellos era inimaginable. Ninguna institución -monasterios, casas, hospitales, obras públicas, iglesias, el cabildo, entre otros- funcionó sin la mano de obra de los negros o los mulatos. Y la vida urbana causó profundos cambios en su personalidad, tal como expresa Carmen Bernard:

"a pesar de tratarse de seres que carecieron por definición de libertad, los que vivieron en las ciudades de Hispanoamérica, desde la Conquista hasta los primeros brotes independentistas, poseyeron características sociológicas y culturales muy distintas a las de aquellos que trabajaron en las plantaciones tropicales o las minas de oro"44.

En ella, los esclavos habrían encontrado algunas herramientas que facilitaron su proceso de manumisión, en la casa o en la calle.

En Santiago, la principal demanda de esclavos se hizo para el servicio doméstico durante el siglo XVIII. No hubo casa decente que prescindiera de ellos y hasta los sectores más modestos procuraron tener, aunque fuera una pieza. En la casa operó una división del trabajo de acuerdo al género y la edad. Las mujeres fueron ocupadas, mayormente, en oficios relacionados a los menesteres hogareños. Un ama describe a María Muñoz: "teniendo esta criada buenos y particulares servicios dignos de recomendarse cuales son saber cocinar para de cualesquiera exquisito uso, lavar y cocer prolijamente y últimamente su pericia en cuanto dulce y confitados" ${ }^{45}$. Y, también, debían extender sus labores de madre con los hijos de sus amos. Muchas amamantaban a retoños ajenos. Cuando estaban en la vejez, se dedicaban a instruir a las esclavas más nuevas en las obras del menaje del hogar. Fueron las sirvientas de razón o amas de llaves las de mayor jerarquía. Los hombres asumieron labores acordes a su condición: aquellas que requerían de destreza física. Eran los porteros y guardianes de grandes casas. Los varones de mayor edad y con mayor experiencia fueron caleseros.

La casa fue un espacio doméstico de convivencia cotidiana. La cercanía con los amos, el servicio personal prolongado en el tiempo, la obediencia y la lealtad fueron configurando relaciones de confianza y afecto mutuos. La mayoría de las cartas de libertad menciona que la otorgan por "las sobradas muestras de amor", "por quererla como a hija y hermana" y "por haberme criado desde niña". Un caso extraordinario de amor y confidencia es el don Alonso Lecaros con el negro Antonio. Su amo

"hacía tanta estimación de el negro Antonio que en una ocasión expresó al declarante que le tenía al dicho Antonio un garrotillo con su látigo para que cuando el doctor José

43 Hünefeldt, op. cit., 1. La traducción es nuestra.

44 Carmen Bernard, Negros esclavos y libres en las ciudades hispanoamericanas, Madrid, Fundación Histórica Tavera, 2001, 11.

45 María Muñoz, esclava, pide carta de venta. Santiago, 1794, ANCH, Real Audiencia (en adelante ANCH, RA), volumen, 2.874, ff. 300-300 vta. 
Antonio Lecaros le pasase a su casa estuviese el negro con los hijos de dicho don Antonio reprendiéndolos, y estos le habrían de llamar taita Antonio"46.

Pero no debemos dar una imagen idílica de la esclavitud doméstica. Es más, el cuerpo de Antonio terminó fragmentado y exhibido en diferentes puntos de la ciudad: fue la pena que le impuso la Real Audiencia por asesinar a su amo.

En las familias de la élite, la vigilancia era superior y, por lo mismo, se requería de mayor disciplina y docilidad. Allí, los esclavos, a sus labores económicas, unieron una función estética. Y debían mostrarse más obedientes, porque, como "signos de distinción social, eran en cierta medida metáforas carnales de sus amos, por ende reflejo de lo que ocurría más allá de donde la mayoría de las miradas alcanzaban a entrar: la casa"47. Doña María Mercedes aseguraba que su esclava Paula tenía los vicios de "insujeta y de depravadas costumbres" 48 . Por lo mismo, le aplicó varios azotes a la mulata

"para que reconociera la servidumbre en que estaba constituida, y le sirviese de algún amago, como y más principalmente para contenerla por este medio tan suave, de sus licenciosas libertades y reducirla al recogimiento que debe guardar, así por ser esclava, como porque sus pocos años, y perversas inclinaciones la inducen a andar siempre fugitiva, viviendo a sus anchuras" 49 .

La casa, también, fue un espacio multiétnico y de pieles policromáticas, sobre todo después de 1713. El Tratado de Utrecht permitió, primero, el influjo constante de 400 esclavos negros de África y, luego, una llegada irregular de mulatos y zambos de contrabando. En una misma vivienda pudieron convivir diferentes grupos sociorraciales -negros, mulatos y zambos- y con distinto origen -criollos o guinea, malaque, angola-. Cada uno de ellos, por lo demás, con disímiles grados de asimilación de la cultura hispana: bozales o ladinos; infieles o bautizados. También, con variadas edades. Un caso ilustrativo es el de doña Mariana Sobarzo. Viuda de don Juan Luis Caldera, mantuvo no menos de 15 esclavos en su vivienda. Este suceso nos consta por su inventario realizado en Santiago, el 23 de abril de 1725. El escribano José Álvarez de Henostroza describe la diversidad de los esclavos:

"Ítem. Petrona samba natural de la otra banda de treinta y cuatro años más o menos Ítem. Bartola mulata de cuarenta y cinco años

Ítem. Isabel negra de guinea de la misma edad Ítem. Agustina negra bozal de veinte y cuatro años

Ítem. Un negro bozal Matías de diez y siete a diez y ocho años que está asistiendo al maestro don Alonso de Herrera canónigo de esta ciudad

46 Carolina González, "Subordinaciones y resistencias de la servidumbre esclava: El caso del negro Antonio (Santiago de Chile, 1776-68)", en Cuadernos de Historia de la Universidad de Chile 25, Santiago, 2006, 123.

47 Ibid., 126.

48 Juicio por sevicia de la mulata Paula contra su ama doña María Mercedes Maradiaga. Santiago, 1759, ANCH, RA, volumen 2.468, f. 256.

49 Ibid., f. 259. 
Ítem. Cinco mulatillos nombrados Manuel de once años, Antonio de siete años, Joseph de cinco años, Juan de trece y Joseph de veinte y cuatro días = hijos de la dicha Petrona Ítem. Pascuala samba natural de esta ciudad de veinte y cinco años con una cría de pecho nombrado Pascual Bailón y otra hija pequeña de dos años nombrada María del Carmen Ítem. Un mulato nombrado Miguel de edad de diez y siete años más o menos"50.

Las relaciones entre amos y esclavos variaron de acuerdo al estatus socioeconómico de las familias y el número de sus integrantes. En la medida que hubiese más personas que servir mayores serían las exigencias. También, era distinta, dependiendo del número de esclavos que habitara la casa. Las tareas habrían estado diversificadas y los esfuerzos en energía y en tiempo laboral habrían sido menores. Pero estar dentro de la casa presentó algunas ventajas para aquellos que quisieran obtener su libertad o conseguir algunas mejoras en su condición de vida: la proximidad física con los amos, que originó vínculos afectivos y conocimiento de su intimidad.

Sin embargo, la casa no fue el único espacio en el cual fueron adquiriendo experiencias para acceder a su libertad. Según Carmen Bernard, "los esclavos residen generalmente - pero no necesariamente- con los vecinos y, por consiguiente, lejos de estar relegados a un barrio específico, ocupan la totalidad del espacio urbano, tanto el privado de las casas como el público" 51 . Uno de los fenómenos más importantes de la esclavitud urbana fue la conversión del esclavo en un jornalero. Es decir, el permiso que obtenía de sus amos para salir a trabajar a la calle, a cambio de la entrega de un porcentaje diario o mensual del sueldo que obtenía. Este dependía de su precio. El 5 de agosto de 1719 doña Elvira Tello, viuda, le daba permiso a María Josefa, su esclava de 28 años: "para que trabaje libremente sin pensión de jornales y que se aproveche del útil de lo que adquiere" 52 .

La estructura laboral -basada en la etnicidad- dejó en sus manos solo los oficios artesanales, considerados como "viles" o "de judíos” por la élite. Así, los esclavos de Santiago cumplieron las mismas funciones que sus homólogos de Lima, Buenos Aires y México. El 14 de julio de 1700 se patentó otro permiso. Este vez se presentó Sebastián de Collados, "negro esclavo de doña Marcela de Meneses maestro zapatero que de consentimiento de la dicha su ama ejerce en tienda pública el oficio de maestro zapatero y trata y contrata en dicho su oficio en lo tocante a Lázaro Carmona asimismo maestro zapatero" 53.

Esta modalidad fue bastante usual en Santiago y habría implicado, necesariamente, una negociación para arrancar algunos privilegios de los amos. No contamos con documentos específicos para conocer en profundidad los detalles de este

50 Inventario de los bienes de María Zobarzo. Santiago, 23 de abril, 1725, ANCH, ES, volumen 522, f. 293 vta. Incluso más, en su testamento consta que regaló una negra Nicolasa a su hermano y que, también, donó a "Doña Juana Caldera su hija religiosa del ministerio de Santa Clara una samba su esclava nombrada Rita tasada en cuatrocientos y cincuenta pesos”, ibid., f. 180.

51 Bernard, op. cit., 13.

52 Carta de libertad a María Josefa. Santiago, 5 de agosto, 1719, ANCH, ES, volumen 611, f. 241.

53 Concierto de Lázaro Carmona, pardo libre, con Sebastián de Collados, negro esclavo. Santiago, 14 de julio, 1700, ibid., volumen 409, f. 159 
acuerdo. Incluso, muchas veces, los amos y amas pobres decidieron darle trabajo obligado a sus esclavos para obtener una mayor rentabilidad y así evitar los gastos de su manutención en alimento y vestuario, porque "los ingresos que podían generar los esclavos hacían una gran diferencia en los estilos de vida de una viuda" 54 . Sin embargo, sea por petición del esclavo o coerción del amo, los jornaleros contaron con una mayor capacidad para acumular capital y, más importante aún, de acelerar su proceso de manumisión. Ningún amo se habría expuesto a sacar a la calle a un esclavo que tuviese antecedentes de cimarrón. Por lo mismo, era una opción que, de cualquier modo, se ganaba por un buen comportamiento, obediencia y lealtad. Y tampoco un esclavo se habría fugado, luego de recibir un mínimo de confianza.

El acceso a la calle proporcionó a los esclavos no solo una capacidad de ahorro mayor. Su movilidad geográfica y la lejanía momentánea del amo le otorgaron un mayor grado de autonomía relativa. También, enfrentarse a la ciudad y manejar un oficio les brindó una excelente oportunidad de extender sus lazos y vínculos sociales, en momentos en que Santiago experimentaba un crecimiento urbano hacia los arrabales. Desde comienzos del siglo XVIII y producto del influjo poblacional sostenido, la ciudad se ensanchó hacia el norte, en el barrio de La Chimba, y al surponiente, en el sector de La Cañada. Se formaron barrios multiétnicos compuestos por españoles y extranjeros pobres, negros y mulatos -libres o libertos-, indios y mestizos ${ }^{55}$. Y fue, en este escenario, en el que pudieron extender sus redes de clientelas.

No menos importante fue el rol que cumplió la Iglesia y las instituciones de justicia. Entre las calles de la ciudad circuló el rumor que sirvió como una experiencia de eventual aprendizaje para interiorizarse de los diferentes recovecos legales para conocer sus derechos y entablar demandas. Hünefeldt describe de forma brillante el nuevo escenario que presentó la ciudad a los esclavos de Lima, un contexto que no difiere con el que experimentaron los de Santiago:

"El traslado a la ciudad -o, si se quiere ver este proceso a partir del hecho consumado, esto es, del incremento de los esclavos en el contexto urbano- marca un cambio en la estructura de dominación esclavista, aunque no necesariamente la abolición del sistema. Las actividades de los esclavos se hacen más especializadas y se suplen, en parte, servicios cada vez más demandados por una población urbana en crecimiento, al tiempo que amplían los espacios de negociación entre esclavos y amos y la velocidad de la automanumisión. El Estado y la Iglesia, de su parte, definen más claramente su intromisión en vida de los esclavos y en las relaciones amos-esclavos" 56 .

Y, en estas circunstancias, algunos con más ventajas y herramientas no se conformaron solo con respirar el aire de la libertad que les brindó la ciudad.

54 Herbert Klein y Ben Vinson III, La esclavitud africana en América Latina y el Caribe, Lima, Instituto de Estudios Peruanos, 2008, 41.

55 De Ramón, op . cit., 92.

56 Christine Hünefeldt, Lasmanuelos: vida cotidiana de una familia negra en la Lima del siglo XIX: Una reflexión sobre la esclavitud urbana, Lima, Instituto de Estudios Peruanos, 1992, 2. 


\section{Las caras de la libertad: búsqueda y significado}

Detengámonos a realizar una pequeña reflexión sobre el significado que tuvo la libertad en el siglo XVIII. Carmen Bernard postula que "no es la antítesis de la esclavitud"57. Según Las Siete Partidas era el "poderío que tiene todo hombre de hacer lo que quisiere, solo que la fuerza o el derecho de la ley no se lo embargue" 58 . Pero las percepciones variaron con la experiencia cotidiana y esto le dio a la esclavitud y la libertad el carácter de valores relativos y cambiantes.

Para la mulata Petrona, el cariño paternalista que sintió por ella su amo se transformó en un obstáculo para su libertad. En 1738, Pedro Ibáñez García se dirigió ante el escribano para manumitirla. Desde que la había comprado en Buenos Aires, quince años atrás, siempre le sirvió con "mucho amor, honra y buena fe, sin haberle dado motivo de disgusto no solo en esta dicha ciudad y reino, sino en otras partes y lugares donde ha andado trayéndola consigo" 59 . Y aunque "en correspondencia de su fidelidad la considera acreedora a su total libertad" 60 , la otorgaba solo después de su fallecimiento. Por eso, obligó a sus familiares a no venderla, pues su deseo era "que la dicha esclava le asista y que otra ninguna persona se sirva de ella"61. Para alivio de la mulata le dejó algunos bienes para pagar sus deudas y se comprometía a no "obligarla a mis dependencias crímenes u otras acciones más" 62 .

Petrona habría debido conformarse con la postergación de su libertad hasta la muerte de su amo y valorar, en adelante, los aspectos positivos de la esclavitud para poder sobrellevarla. Mal que mal, le ofrecía la garantía de servicios básicos: vestimenta, salud, alimentación y seguridad. Dentro de su estado servil podría, eventualmente, favorecerse del sistema. Su amo, bajo su óptica, estaba beneficiando a su esclava con privilegios y franquicias que no eran comunes en la época.

Para otros esclavos, sin embargo, la misma libertad alcanzó la dimensión de una verdadera pesadilla en vida, con características de una parodia burlesca, y no difirió, en rigor, de la esclavitud. Don Fernando Marmolejo y Bustos y doña Antonia de Ulloa y Mercado, marido y mujer, decidieron manumitir a su esclavo Manuel del Carmen Marmolejo. Su madre, la negra Gregoria Ulloa, había muerto al dar a luz, por lo que sus amos lo criaron como hijo propio. Ambos se encargaron de darle al protocolo un carácter benéfico, pues no medió ningún pago por su acción: fue una libertad graciosa para, también, agradecer los servicios de su madre. El mulato, según el escribano, estuvo presente y quizás habría escuchado cómo dictaban el documento en la escribanía. Su cara, seguramente, habría cambiado de color si hubiese entendido los alcances del protocolo, pero solo tenía 7 años. Su manumisión se haría efectiva solo con cuatro condiciones. Hasta los cincuenta años debía asistir a la iglesia de San Juan de Dios los martes y "con un

\footnotetext{
57 Bernard, op. cit., 18.

58 Cuarta Partida, Título XXII.

59 Oferta de libertad a Petrona. Santiago, 17 de mayo, 1738, ANCH, ES, volumen 650, f. 174.

60 Idem.

61 Idem.

62 Idem.
} 
plumero que le darán los mayordomos de la cofradía de Nuestra Señora del Carmen ha de limpiar, sacudir y asear su altar y las demás de esta dicha Iglesia"63; el miércoles por la mañana debería repetir sus labores para la misa de la Virgen "y caso que sepa tocar arpa u otro cualesquier instrumentos ha de ser obligado a asistir con él en la dicha misa sin llevar interés alguno a la cofradía"64. El documento continuaba: "asimismo ha de ser obligado en la misma forma y manera de suso referido y con el dicho instrumento el día de la festividad del glorioso patriarca San Juan de Dios"65. Concluía con la siguiente cláusula: "Y asimismo es condición expresa de esta escritura que durante los días de la vida de los otorgantes no ha de ser osado ni intentar salirse de la casa y poder de los susodichos con pretexto alguno porque ha de estar sujeto a la corrección y doctrina de los dichos otorgantes"66. Ambos, finalizaban, obligándose a reconocer "en bastante forma de derecho que esta libertad le será cierta y segura"67.

Ambos casos demuestran los diversos y disímiles significados que tuvieron la esclavitud y la libertad entre amos y esclavos. Diferentes obstáculos -el cariño excesivo del amo como ocurrió a Petrona y la exigencia de una disciplina previa a la vida como liberto, en el caso de Manuel del Carmen- produjeron, en la práctica, una relatividad (y por qué no, ambigüedad) en las nociones sobre esos términos. La libertad fue, en definitiva, un concepto cuya percepción varió de acuerdo a las distintas circunstancias empíricas de los sujetos implicados.

Su alcance, también, era restringido. Según las cartas de libertad, los esclavos, una vez libres, se constituían en un nuevo sujeto jurídico con derechos y deberes: podían utilizar la libertad de tráfico, mudarse de un reino a otro; tratar y contratar con otras personas sin intermedio de terceros; comparecer por sí en los tribunales de justicia; disponer de sus bienes a su elección; y, además, poseían plena facultad para otorgar su testamento frente a un escribano. Pero limitado y todo les permitía experimentar algo que nunca habían sentido: ser dueños de su propio destino. O, por lo menos, del que les dejaba la sociedad en que les tocó vivir.

Su relatividad y carácter restringido habría provocado que, en la cotidianidad, se presentara como una meta posible. Por lo mismo, Orlando Patterson menciona que, más que la búsqueda imperecedera de la libertad, la principal aspiración de los esclavos fue establecer relaciones horizontales y buscar mejoras en su condición cotidiana $^{68}$. En este sentido, la libertad podía ser una de ellas, pero no la única. Por esta razón, Bárbara Fields postula que poner fin a su estado de esclavitud "no era un objetivo definido de una vez y para siempre. En los hechos aparece como una meta flexible y en constante movimiento"69. Aguirre, en concordancia con esos

63 Carta de libertad a Manuel del Carmen. Santiago, 13 de agosto, 1705, ibid., volumen 459, f. 217.

64 Idem.

65 Idem.

66 Idem.

67 Idem. Las cursivas son nuestras.

68 Orlando Patterson, Slavery and Social Death, Camdridge, Harvard University Press, 1982.

69 Citado por Rebecca Scott, "Exploring the meaning of freedom: postemancipation societies in comparative perspective", en Hispanic American Historical Review 68:3, Durham, 1988, 426. 
autores, agrega que "se trataba de una aspiración sujeta a las contingencias de la vida, cuya reivindicación dependía de los ajustes que se fueran dando en la relación amo-esclavo"70. ¿Cuándo ocurrió ese momento "de ajuste", por lo menos, para los esclavos de Santiago?

\section{LA MANUMISIÓN DE ESCLAVOS EN SANTIAGO: UN ANÁLISIS CUANTITATIVO}

Hemos examinado el proceso de fijación de precios de los esclavos en el mercado de Santiago, las oportunidades y conocimientos diversos que pudieron obtener en la ciudad -dentro de la casa o trabajando en la calle- y, también, las opciones y evaluaciones que hicieron sobre la libertad como una meta operable y alcanzable en una sociedad en que la esclavitud fue un fenómeno ampliamente extendido y legitimado por diversos sectores de la población. En esta sección, esbozaremos un análisis estadístico de la manumisión en Santiago para conocer las características de los amos y esclavos que participaron en este proceso, sondear el grado de permeabilidad del régimen y conocer las motivaciones que guiaron sus acciones.

La serie de cuadros y gráficos que se presentan a continuación está basada en la catalogación de 83 casos en que los esclavos consiguieron su manumisión entre 1698 y 1750 . Si bien esta fuente es idéntica para las distintas realidades latinoamericanas, no es nuestra intención realizar un análisis comparativo exhaustivo. Los contextos en que se han hecho los distintos estudios para Buenos Aires, Lima, Bahía, Paraty y México son diversos. Pero, a pesar de lo anterior, podemos esbozar un paralelo para resaltar las diferencias que hacen de la manumisión en Santiago un caso distinto.

\section{Amos y esclavos en cifras}

Como nuestro interés es sondear el momento en que ocurrió la manumisión, debemos analizar las características de los amos, que son, en definitiva, quienes tienen la facultad privativa de brindarla. Entre 1698 y 1750 , el 68,0\% de las manumisiones fue otorgada por mujeres y solo el 25,0\% por hombres (ver cuadro $\mathrm{N}^{\circ} 1$ ). Las proporciones no cambian, sustantivamente, si establecemos el Tratado de Utrecht como hito de un paulatino proceso de devaluación de los precios de los esclavos: entre 1698 y 1713 la participación femenina alcanza el 79,5\% y después baja al 57,8\%, pero, en ambos periodos, son la mayoría. Una de las hipótesis que aún se sostiene en algunas investigaciones es la alta tasa de esclavos que consiguieron su libertad producto de una relación ilegítima entre amos y esclavas $^{71}$. Pero, con estos datos, este planteamiento disminuye su fuerza. Sin embargo, los amos varones aumentan su participación después de 1713: del 17,6 al 31,6\%.

\footnotetext{
70 Aguirre, op. cit., 213.

71 Rosa Soto, La mujer negra en el Reino de Chile, Tesis de Magíster en Historia, Universidad de Santiago de Chile, 1988. De todos modos, esto no le resta ningún mérito al resto de su trabajo, un análisis pionero sobre las mujeres esclavas en el Chile colonial.
} 


\section{CUADRO $\mathrm{N}^{\circ} 1$}

SEXO DE LOS AMOS Y CANTIDAD DE LIBERTADES OTORGADAS EN SANTIAGO DE CHILE

(1698-1750)

\begin{tabular}{|c|c|c|c|c|c|c|}
\hline \multirow[b]{2}{*}{ Sexo } & \multicolumn{2}{|c|}{$1698-1713$} & \multicolumn{2}{|c|}{ 1713-1750 } & \multicolumn{2}{|c|}{$1698-1750$} \\
\hline & $\mathrm{N}^{\mathrm{o}}$ & $\%$ & $\mathrm{~N}^{\circ}$ & $\%$ & $\mathrm{~N}^{\circ}$ & $\%$ \\
\hline Mujer & 27 & 79,5 & 22 & 57,8 & 49 & 68,0 \\
\hline Hombre & 6 & 17,6 & 12 & 31,6 & 18 & 25,0 \\
\hline Ambos & 1 & 2,9 & 4 & 10,5 & 5 & 7,0 \\
\hline Total & 34 & & 38 & & 72 & 100 \\
\hline
\end{tabular}

La libertad de esclavos en Santiago, desde el punto de vista patronal, fue un ejercicio eminentemente femenino y esta característica es la que la hace peculiar dentro de las ciudades latinoamericanas en las cuales se encuentran los datos del sexo de los amos. En Buenos Aires, el estudio de Lyman Johnson evidenció que la participación de las mujeres en la manumisión fue bajísima: las amas intervinieron en el 33,0\% de los casos, mientras que los amos alcanzan el 62,0\%. En Bahía, los resultados de Stuart Schwartz revelan que la proporción alcanza a 40,8\% de mujeres y un $57,7 \%$ los hombres (ver cuadro $\mathrm{N}^{\circ} 2$ ).

\section{CUADRO $\mathrm{N}^{\circ} 2$}

PORCENTAJE DE PARTICIPACIÓN DE LOS AMOS SEGÚN EL SEXO EN CIUDADES DE AMÉRICA HISPANA Y PORTUGUESA ${ }^{72}$

\begin{tabular}{lccc}
\hline Bmos & Buenos Aires & Bahía & Santiago \\
$1776-1810$ & $1684-1745$ & $1698-1750$ \\
\hline Mujer & 33,0 & 40,8 & 68,0 \\
Hombre & 62,0 & 57,7 & 25,0 \\
Ambos & 5,0 & 1,5 & 7,0 \\
\hline
\end{tabular}

Un dato que nos puede iluminar más sobre las características del proceso de manumisión en Santiago es el estado civil de las mujeres. Entre 1698 y 1750 el $58,3 \%$ de las amas que otorgaron la libertad fueron viudas. Estas proporciones no cambian cuando las comparamos entre periodos. A pesar de la devaluación de precios, las viudas son quienes, mayoritariamente, otorgan las manumisiones: en el $66,8 \%$ de los casos antes de 1713 y en un 50,1\% luego de esa fecha (ver cuadro $\mathrm{N}^{\circ}$ 3). También, después de 1713, aparece en los registros una parda libre, soltera, lo que refuerza nuestro planteamiento acerca de la complejidad y diversidad de las relaciones amo-esclavo en Santiago.

72 Fuente: (Buenos Aires) Johnson, "Manumission in colonial...", op. cit., 266; (Bahía) Schwartz, op. cit., 622 . 


\section{CUADRO $\mathrm{N}^{\circ} 3$}

ESTADO CIVIL Y/O OCUPACIÓN DE LAS AMAS QUE OTORGAN LA MANUMISIÓN EN SANTIAGO DE CHILE

$(1698-1750)$

\begin{tabular}{|c|c|c|c|c|c|c|c|c|}
\hline \multicolumn{3}{|c|}{$1698-1713$} & \multicolumn{3}{|c|}{$1713-1750$} & \multicolumn{3}{|c|}{ 1698-1750 } \\
\hline Amas & $\mathrm{N}^{\circ}$ & $\%$ & Amas & $\mathrm{N}^{\circ}$ & $\%$ & Amas & $\mathrm{N}^{\circ}$ & $\%$ \\
\hline Viuda & 16 & 66,8 & Viuda & 12 & 50,1 & Viuda & 28 & 58,3 \\
\hline Soltera & 3 & 12,5 & Soltera & 4 & 16,6 & Soltera & 7 & 14,6 \\
\hline Casada & 1 & 4,1 & Casada & 5 & 20,8 & Casada & 6 & 12,5 \\
\hline Monja & 4 & 16,6 & Monja & 2 & 8,3 & Monja & 6 & 12,5 \\
\hline & & & Parda libre & 1 & 4,2 & Parda libre & 1 & 2,1 \\
\hline Total & 24 & & & 24 & & & 48 & 100 \\
\hline
\end{tabular}

En el caso de los hombres es difícil conocer su estado civil. A diferencia de las mujeres, ellos no necesitaban de la tutela de su cónyuge para realizar transacciones. Las cartas de libertad mencionan solo su calidad de vecinos y, también, el grado militar: alférez, maestre de campo, capitán, entre otros, por lo que es imposible conocer, también, su nivel socioeconómico. De todos modos, de los 18 amos que liberaron esclavos entre 1698 y 1713, 4 eran curas, 1 comerciante, 1 abogado de la Real Audiencia y el resto son vecinos (ver cuadro $\mathrm{N}^{\circ} 4$ ). De los hombres laicos, solo 4 reconocieron su paternidad ilegítima.

\section{CUADRO $\mathrm{N}^{\circ} 4$}

OCUPACIÓN DE LOS AMOS EN SANTIAGO DE CHILE $(1698-1750)$

\begin{tabular}{lc}
\hline Hombres & $\mathrm{N}^{\circ}$ \\
\hline Cura & 4 \\
Abogado & 1 \\
Soltero & 1 \\
Comerciante & 1 \\
Vecinos & 8 \\
No dice & 3 \\
Total & 18 \\
\hline
\end{tabular}

En cuanto a los esclavos, los mulatos de Santiago fueron quienes alcanzaron con mayor anuencia la manumisión entre 1698 y 1750: en el 84,4\% de los casos, en contraste con el 15,6\% de los negros (ver cuadro $\mathrm{N}^{\circ}$ 5). En Buenos Aires y Bahía, Johnson y Schwartz, respectivamente, explican que la preponderancia de una casta expresa, primeramente, una correspondencia con la proporción que ocu- 
pan en la demografía ${ }^{73}$. Según el censo de 1778, los mulatos en Santiago eran el $15,2 \%$ y los negros, apenas, un 3,6\% ${ }^{74}$. Distinta es la situación en esas ciudades: la capital del virreinato de La Plata recibió importaciones directas de africanos para la construcción de defensas portuarias, mientras que Bahía y Paraty, para las plantaciones de azúcar.

\section{CUADRO $\mathrm{N}^{\mathrm{O}} 5$}

\section{MANUMISIÓN DE ESCLAVOS EN AMÉRICA HISPANA Y PORTUGUESA: COMPARACIÓN POR COLOR, SEXO Y TIPO DE MANUMISIÓN ${ }^{75}$}

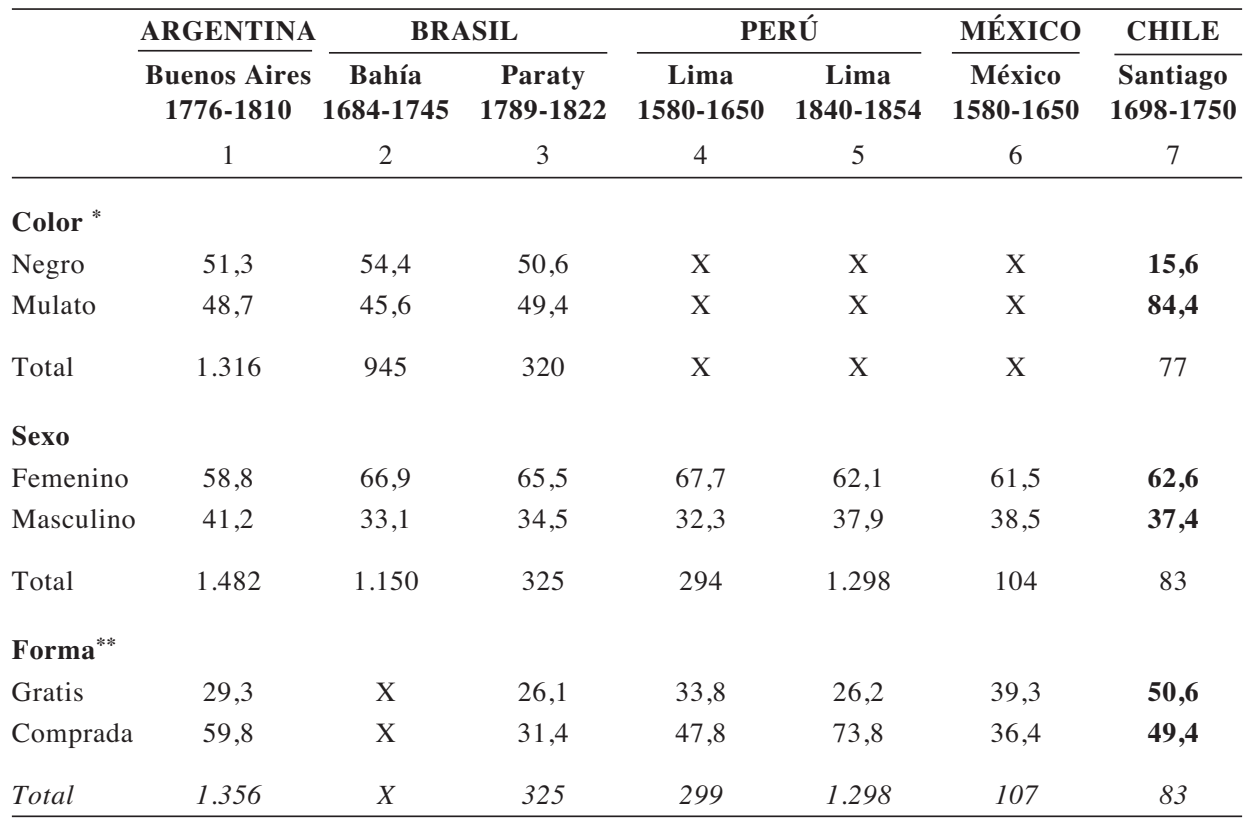

Utilizamos la categoría color, puesto que era la que aparecía en la mayoría de los estudios sobre la manumisión. No obstante, el uso de los términos negros, mulatos y zambos es aleatorio y completamente subjetivo por parte de los diferentes escribanos de Santiago. Fue un funcionario que actuó como filtro sociorracial, pues él es quien anota el color de los esclavos. Si bien en Santiago y en América Latina las categorías son ambiguas, me basé en la nomenclatura original de las cartas de libertad, tal cual lo hicieron los pioneros del análisis comparativo.

** Cada uno de los historiadores, sobre todo quienes comenzaron con el análisis más temprano, usaron diferentes clasificaciones para el tipo de libertad. Por lo mismo, tuve que reelaborar muchos de los datos de sus estudios y gráficos para encajarlos en las categorías analíticas usadas por los más modernos y, también, en Santiago. Nos facilitó la tarea el estudio de Lyman Johnson en Buenos Aires, quien utilizó el mismo criterio. Johnson, "Manumission in colonial...", op. cit., 262.

73 Johnson, "Manumission in colonial...", op. cit., 261.

74 Carmagnani y Klein, op. cit.

75 Fuente: (1) Johnson, "Manumission in colonial...", op. cit.; (2) Schwartz, op. cit.; (3) Kiernan, op. cit.; (4) Bowser, op. cit.; (5) Aguirre, op. cit.; (6) Bowser, op. cit.; (7) 72 cartas de libertad del Fondo de Escribanos de Santiago, en las cuales se libera a 83 esclavos. 
Pero no todo radica en su densidad en la estructura demográfica, sino que, también, en su origen. De los mulatos y negros liberados en Santiago entre 1698 y 1750 todos fueron criollos $(100 \%)$ y no se presentó ningún caso de algún esclavo procedente de África. Al ser ladinos, habrían contado con mayores ventajas lingüísticas y culturales para acercarse a negociar la libertad con sus amos. El mismo fenómeno se observa en Bahía: los mulatos y negros criollos alcanzaron el $69 \%$ y los africanos solo el 31\%. Los datos de Kiernan, en Paraty, siguen el mismo patrón: un $84,4 \%$ de los esclavos nacieron en Brasil, mientras que solo el 15,6\% llegó desde África (ver cuadro $N^{\circ}$ 6). Para Buenos Aires, México y Lima no es posible extraer esos datos.

\section{CUADRO N ${ }^{\circ} 6$}

\section{PORCENTAJE DE LIBERTADES SEGÚN EL ORIGEN DE LOS ESCLAVOS} EN DISTINTAS CIUDADES DE AMÉRICA HISPANA Y PORTUGUESA ${ }^{76}$

\begin{tabular}{lccc}
\hline Oahía & Paraty & Santiago \\
Origen & $1684-1745$ & $1789-1822$ & $1698-1750$ \\
\hline Criollo & 69,0 & 84,4 & $\mathbf{1 0 0}$ \\
Africano & 31,0 & 15,6 & $\mathbf{0 , 0}$ \\
\hline
\end{tabular}

Otra variable importante es la procedencia de los esclavos. Las relaciones con sus amos habrían sido bastante heterogéneas si ellos provenían de una compra, de una herencia o estuvieron desde pequeños en la casa de sus amos. Aquellos nacidos en el hogar habrían contado con una mayor capacidad para interiorizarse y compenetrarse con sus valores y patrones culturales. Lo mismo habría ocurrido con los heredados, puesto que, por lo general, habrían socializado con sus futuros dueños. Esto les habría dado una ventaja mayor para manipular las variables de su entorno a su favor, o bien se habrían acomodado de forma consciente al sistema. Desde la óptica patronal, esta situación habría facilitado que los amos inclinaran su psicología a percibir su dimensión más humana, en detrimento de su estimación únicamente como objeto ${ }^{77}$. En Santiago, entre 1698 y 1750 , el $58,2 \%$ de quienes consiguieron su manumisión aparece con el rótulo "nacido y criado en mi casa"; el 22,5\% fue parte de una herencia y solo un 19,3\% fue comprado (ver cuadro $\mathrm{N}^{\circ} 7$ ).

76 Schwartz, op. cit., 612.; Kiernan, op. cit., 64. De este último autor, reelaboramos los datos para el caso de Paraty que aparecen en "Table 7: Color of libertos".

77 Schwartz, op. cit., 621-622. El autor postula que, en el caso de Bahía, un gran porcentaje de los esclavos nacidos en la casa generaron en los amos un sentimiento afectivo que él llama "surrogate paternity or maternity", debido a los mayores lazos que se originaron por estar toda una vida junto a ellos y, también, por presenciar el nacimiento de uno. 


\section{CUADRO $\mathrm{N}^{\circ} 7$}

\section{CANTIDAD DE LIBERTADES SEGÚN PROCEDENCIA DEL ESCLAVO EN SANTIAGO DE CHILE}

(1698-1750)

\begin{tabular}{|c|c|c|c|c|c|c|}
\hline \multirow[b]{2}{*}{ Procedencia } & \multicolumn{2}{|c|}{$1698-1713$} & \multicolumn{2}{|c|}{ 1713-1750 } & \multicolumn{2}{|c|}{ 1698-1750 } \\
\hline & $\mathrm{N}^{\circ}$ & $\%$ & $\mathrm{~N}^{\circ}$ & $\%$ & $\mathrm{~N}^{\circ}$ & $\%$ \\
\hline Comprados & 6 & 22,2 & 6 & 17,1 & 12 & 19,3 \\
\hline Herencia o dote & 8 & 29,6 & 6 & 17,1 & 14 & 22,5 \\
\hline Nacidos en casa & 13 & 48,2 & 23 & 65,7 & 36 & 58,2 \\
\hline Total & 27 & & 35 & & 62 & 100 \\
\hline No dice & 10 & & 11 & & 21 & \\
\hline
\end{tabular}

En cuanto al sexo, entre 1698 y 1750, las mujeres esclavas de Santiago consiguieron un mayor número de libertades: en un $62,6 \%$ de los casos, en detrimento del $37,4 \%$ que obtuvieron los hombres, una tendencia que se repite en las ciudades de América hispana y portuguesa como Buenos Aires, Bahía, Paraty, México y Lima (ver cuadro $N^{\circ}$ 5). En Santiago, el hecho tiene varias explicaciones: eran más numerosas y los familiares habrían optado por liberar a las esclavas para asegurar una descendencia disociada de la experiencia de la esclavitud ${ }^{78}$. Lyman Johnson detalla las consecuencias que tuvo este fenómeno en el aumento de la población libre. "No fue la cantidad de manumisiones, sino el sexo de los liberados lo que explica ese crecimiento. Dado que los niños heredaron el estatus legal de sus madres, la manumisión de grandes cantidades de mujeres en edad de procrear condujo al crecimiento de la población de color libre a través del incremento natural"79.

En cuanto a la edad, existe un alto porcentaje de cartas de libertad que no mencionan ese dato en nuestro caso: 44,6\%. Omitiendo esas falencias, entre 1698 y 1750 , los esclavos de Santiago del rango etario de 0 a 7 años son quienes mayoritariamente obtienen la manumisión: $45,7 \%$. Incluso, si dividimos la muestra en dos periodos, la tendencia es al alza: de $34,8 \%$ de los casos entre 1698 y 1713, aumentan al 56,5\% después de esa fecha (ver cuadro $N^{\circ} 8$ ). Esto se explica, principalmente, por el bajo costo que tenían a esa edad. Para los amos no representó una mayor pérdida económica. También, fue más fácil para los familiares de los esclavos comprar la libertad de sus parientes, puesto que implicaba un tiempo de ahorro y trabajo menores. Pero el fenómeno más importante -como lo veremos más adelan-

78 Carmagnani y Klein, op. cit. Reelaboramos los datos de la población del corregimiento de Santiago. Según el censo de 1777-1778, la ciudad llegaba a los 38.243 habitantes: 20.980 eran mujeres $(54,9 \%)$ y 17.263 eran hombres $(45,1 \%)$. De la población femenina, $11.111(53 \%)$ eran españolas, $2.981(14,1 \%)$ mestizas, $2.716(13 \%)$ indias, $717(3,5 \%)$ negras y $3.455(16,4 \%)$ mulatas. Las diferencias en la estructura demográfica de estas últimas categorías son abismantes.

79 Lyman Johnson, "La manumisión en el Buenos Aires colonial: un análisis ampliado", en Desarrollo económico. Revista de Ciencias Sociales 17:68, Buenos Aires, 1978, 638-639. 
te- es que la edad estaría relacionada con la estrategia temporal que usaron los esclavos para optar por conseguir su propia libertad o la de un familiar. Por mientras, retengamos esta afirmación.

\section{CUADRO ${ }^{\circ} 8$}

ESCLAVOS MANUMITIDOS SEGÚN SU EDAD EN SANTIAGO DE CHILE (1698-1750)

\begin{tabular}{|c|c|c|c|c|c|c|}
\hline \multirow[b]{2}{*}{ Edad } & \multicolumn{2}{|c|}{$1698-1713$} & \multicolumn{2}{|c|}{ 1713-1750 } & \multicolumn{2}{|c|}{$\begin{array}{l}1698-1750 \\
\end{array}$} \\
\hline & $\overline{\mathrm{N}^{\circ}}$ & $\%$ & $\mathrm{~N}^{\circ}$ & $\%$ & Total & $\%$ \\
\hline 0 a 7 & 8 & 34,8 & 13 & 56,5 & 21 & 45,7 \\
\hline 8 a 15 & 4 & 17,4 & 1 & 4,3 & 5 & 10,8 \\
\hline 16 a 30 & 3 & 13,1 & 3 & 13,1 & 6 & 13,1 \\
\hline 31 a 45 & 5 & 21,7 & 0 & 0,0 & 5 & 10,8 \\
\hline 46 a 60 & 1 & 4,3 & 6 & 26,1 & 7 & 15,2 \\
\hline 60 ó + & 2 & 8,7 & 0 & 0,0 & 2 & 4,4 \\
\hline Total & 23 & & 23 & & 46 & 100 \\
\hline No dice & 12 & & 25 & & 37 & \\
\hline
\end{tabular}

El proceso de manumisión: motivaciones y características

Dos fueron las formas que emplearon los esclavos para conseguir su libertad en Santiago: la remuneratoria, es decir, el pago de su justo precio a cambio de su libertad, y la graciosa, aquella por la cual el amo la otorgaba como donación, causándose un perjuicio patrimonial, en agradecimiento a la lealtad y el buen comportamiento. Entre 1698 y 1750 el 50,6\% de los esclavos, independiente de su sexo, color o edad, obtuvieron su libertad de forma graciosa. En cambio, el 49,4\% desembolsó alguna cantidad de dinero para su manumisión o la de un familiar (ver cuadro $\mathrm{N}^{\circ}$ 9).

\section{CUADRO N ${ }^{\circ} 9$}

FORMAS DE CONSEGUIR LA MANUMISIÓN DE LOS ESCLAVOS EN SANTIAGO DE CHILE

(1698-1750)

\begin{tabular}{|c|c|c|c|c|c|c|}
\hline \multirow[b]{2}{*}{ Tipo } & \multicolumn{2}{|c|}{$1698-1713$} & \multicolumn{2}{|c|}{$1713-1750$} & \multicolumn{2}{|c|}{$1698-1750$} \\
\hline & $\mathrm{N}^{\circ}$ & $\%$ & $\mathrm{~N}^{\circ}$ & $\%$ & $\mathrm{~N}^{\circ}$ & $\%$ \\
\hline Graciosa & 11 & 31,4 & 31 & 64,6 & 42 & 50,6 \\
\hline Remuneratoria & 24 & 68,6 & 17 & 35,4 & 41 & 49,4 \\
\hline Total & 35 & & 48 & & 83 & 100 \\
\hline
\end{tabular}


Sin embargo, si dividimos el periodo en dos, observamos una tendencia distinta. Entre 1698 y 1713 el 68,6\% de los esclavos pagó por su libertad, mientras que para 1713 y 1750 las libertades graciosas suben del 31,4\% al 64,6\% (ver cuadro $\mathrm{N}^{\circ}$ 9). A partir de esa información podríamos establecer que los altos precios anteriores al tratado de Utrecht suscitaron que los amos fueran más reticentes a manumitir a los esclavos de forma graciosa, puesto que se perdía una gran inversión.

Desglosemos las remuneratorias. La libertad alcanzada por medio de un pago podía ocurrir de tres maneras: a) la autocompra: cuando el esclavo reunía el dinero para conseguir su propia manumisión; b) la compra por un familiar; o c) el préstamo de terceros. La manumisión fue difícil de conseguir de forma individual en Santiago y tuvo una baja incidencia entre 1698 y 1750 : solo en un $26,1 \%$ de los casos. Por eso, la estrategia familiar fue la más importante en el largo plazo. Del total del periodo, el 40,4\% fue liberado por un familiar (ver cuadro $\mathrm{N}^{\circ} 10$ ).

CUADRO N ${ }^{\circ} 10$

FORMAS DE PAGO DE SU MANUMISIÓN DE LOS ESCLAVOS POR SEXO EN SANTIAGO DE CHILE

(1698-1750)

\begin{tabular}{|c|c|c|c|c|c|c|c|c|c|c|}
\hline \multirow[b]{2}{*}{ Forma } & \multicolumn{4}{|c|}{ 1698-1713 } & \multicolumn{4}{|c|}{ 1713-1750 } & \multicolumn{2}{|c|}{ 1698-1750 } \\
\hline & Hombre & Mujer & $\mathrm{N}^{\mathrm{o}}$ & $\%$ & Hombre & Mujer & $\mathrm{N}^{\mathrm{o}}$ & $\%$ & $\mathrm{~N}^{\mathrm{o}}$ & $\%$ \\
\hline Autocompra & 4 & 2 & 6 & 25,0 & 1 & 4 & 5 & 27,8 & 11 & 26,1 \\
\hline Familiar & 4 & 3 & 7 & 29,2 & 3 & 7 & 10 & 55,5 & 17 & 40,4 \\
\hline Préstamo de $3^{\circ}$ & 6 & 5 & 11 & 45,8 & 1 & 2 & 3 & 16,7 & 14 & 33,5 \\
\hline Total & & & 24 & & & & 18 & & 42 & 100 \\
\hline
\end{tabular}

Sin embargo, observamos cambios interesantes al hacer una división por periodos. Antes de 1713 el $45,8 \%$ de los esclavos tuvo que endeudarse para conseguir su manumisión, mientras que el porcentaje baja a 16,7\% después de esa fecha (ver cuadro $\left.\mathrm{N}^{\circ} 10\right)$. Esto corroboraría las dificultades que tuvieron los esclavos antes del Tratado de Utrecht: por sus altos precios. Por lo mismo, la característica más decisiva del proceso fue la estrategia familiar. Porque muchos de aquellos que compraron su propia libertad comienzan a liberar a sus familiares.

¿Cómo explicamos que las estrategias sean tan dispares en ambos periodos? En el cuadro $\mathrm{N}^{\circ} 9$ observamos que después de 1713 las manumisiones graciosas aumentan ostensiblemente del $31,4 \%$ al $64,6 \%$, mientras que en el cuadro $\mathrm{N}^{\circ} 10$ las cifras indican que el préstamo decae notoriamente como mecanismo de consecución de la libertad. Con estos datos podríamos afirmar que existe una correlación estrecha entre el movimiento del tráfico, el precio del esclavo en el mercado y el ritmo de la manumisión ${ }^{80}$. Sin embargo, ¿una disminución en el precio provoca, necesariamente, un aumento de las libertades?

80 Patterson, op. cit., 13. Para él, "los modos de reclutamiento de esclavos, el tráfico y la manumisión estuvieron todos íntimamente relacionados". 
Lyman Johnson, en su estudio sobre Buenos Aires tardo-colonial, explica que la existencia de un gran número de manumisiones remuneratorias es sinónimo de un desarrollo de la economía urbana, lo que sugiere que una parte de los esclavos tiene una participación gravitante en la estructura laboral de las ciudades ${ }^{81}$. José Luis Belmonte, en cambio, en su análisis de los mecanismos de liberación en Santiago de Cuba, postula que la tendencia del abastecimiento de esclavos es una variable que debe considerarse. En la ciudad isleña, una vez que se eliminaron las cortapisas legales que desincentivaban la introducción de mano de obra negra, en 1789, "para el propietario, era relativamente sencillo otorgar la libertad porque existía un gran mercado de esclavos donde podría reemplazarlo" 82 .

Considerando los postulados anteriores, las cifras parecieran indicar que, al igual que lo que ocurrió en Cuba, la cantidad de las manumisiones aumentó después de 1713. Pero no existe una correlación directa de causa y efecto entre la baja de precio de los esclavos y la cantidad de manumisiones. El aumento del tráfico no provocó una tendencia abolicionista o una redefinición de las relaciones entre amos y esclavos. Nos inclinamos hacia la visión de Belmonte: el tráfico más expedito luego de la apertura de la cordillera, al momento que amplió y regularizó la oferta del mercado de esclavos de Santiago de Chile (y, conjuntamente, disminuyó su valor), funcionó como un mecanismo de incentivo solo para los amos, en cuanto permitía un recambio expedito del "bien liberado". Sin embargo, aunque este fenómeno habría significado más ventajas para los nuevos esclavos ingresados producto de la apertura cordillerana, las cifras indican lo contrario. Los nacidos y criados en la casa siguen corriendo con ventajas: entre 1698 y 1713 su porcentaje era de $48,2 \%$, el cual sube al $65,7 \%$ entre 1713 y 1750 , mientras que los comprados bajan del $22,2 \%$ al $17,1 \%$, respectivamente (ver cuadro $\mathrm{N}^{\circ} 7$ ).

De todos modos, las cifras de los cuadros $\mathrm{N}^{\circ} 9$ y $\mathrm{N}^{\circ} 10$, más que una falla y/o contradicción metodológica, expresan una decisión económica racional de los esclavos para usar sus recursos. Y esto se conecta con el tema de la edad que mencionamos anteriormente. Efectivamente, el precio de un esclavo estuvo intrínsecamente relacionado a las fluctuaciones de la oferta del mercado internacional -una variable que ellos jamás pudieron controlar-, pero, también, y más importante aún, a su edad. A medida que el tiempo -y su propia vida- transcurría, ellos sabían que, de no mediar una enfermedad extraña o un accidente que mermara su cuerpo -situación que no les favorecía- estaban sujetos a un proceso de avaluación constante.

El gráfico $\mathrm{N}^{\mathrm{o}} 1$ nos muestra la curva de las edades de los esclavos, independiente de su sexo y el color, y su relación con su precio en Santiago. Según los datos, observamos, en general, una tendencia al alza que, entre 1698 y 1713 , alcanza su momento álgido a los 24 años de edad. Para el periodo entre 1713 y 1750, lamentablemente, las cifras están incompletas. El alto porcentaje de libertades graciosas escondió los rangos etarios y su correspondencia con el valor de sus cuerpos. Sin

81 Johnson, "La manumisión en el Buenos Aires...", op. cit., 640.

82 José Luis Belmonte, "Con la plata ganada y su propio esfuerzo. Los mecanismos de manumisión en Santiago de Cuba, 1780-1803", en Revista del Grupo de Estudios Afroamericanos de la Universidad de Barcelona 3, Barcelona, 2005, 7. 
embargo, al parecer, la máxima cuantía se alcanza en el rango de los 30 años, una situación no muy distinta de la que ocurre en el periodo anterior (ver gráfico $\mathrm{N}^{\mathrm{o}} 1$ ). Por eso, se puede plantear que, cuando la edad fue un impedimento para alcanzar la libertad, una de las estrategias de los esclavos fue hacer extensivo ese beneficio a sus familiares, esperando conseguir su libertad de forma graciosa.

GRÁFICO No $1^{83}$

\section{CORRELACIÓN ENTRE LA EDAD Y EL PRECIO DE LOS ESCLAVOS EN SANTIAGO DE CHILE}

(1698-1750)

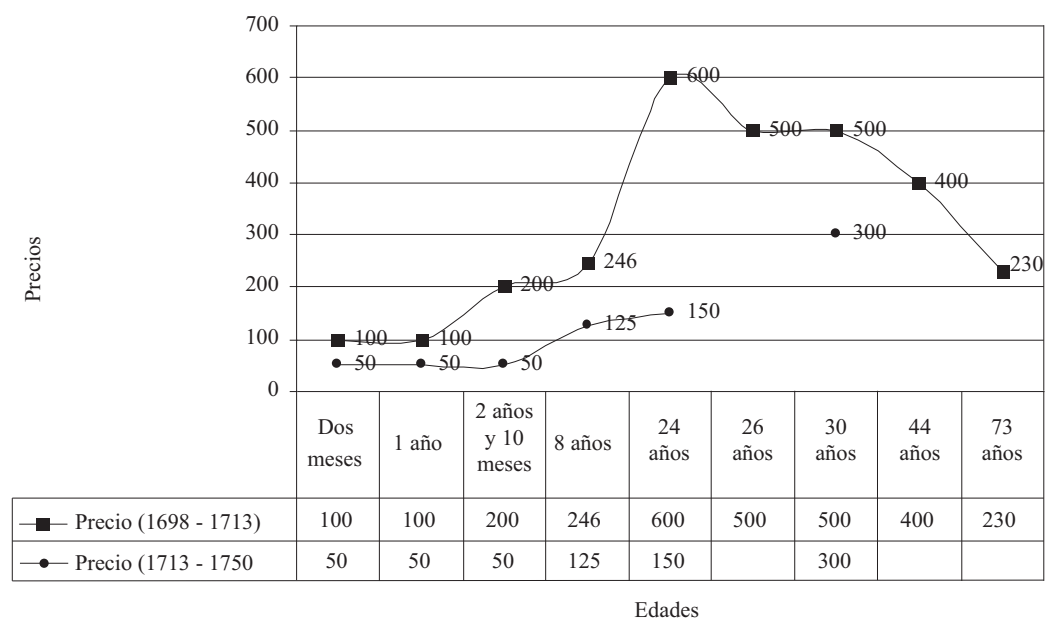

El cuadro $\mathrm{N}^{\circ} 11$ contiene la interrelación de las variables sexo y edad de los esclavos que fueron liberados por sus familiares en Santiago. A pesar del pequeño número de la muestra, por la escasez de los datos, las cifras expresan la racionalidad que usaron a la hora de efectuar esa decisión y sus motivaciones. Entre 1698 y 1750 el $59 \%$ de los esclavos manumitidos fueron hombres y mujeres de 0 a 7 años, mientras que el $23,5 \%$ se ubicó en el rango etario de 8 a 15 años (ver cuadro $\mathrm{N}^{\circ}$ 11). Ambos grupos etarios representan, juntos, el $82,5 \%$ de los casos. Según las cartas de ahorramiento, los precios de esclavos entre 0 a 15 años fluctuaron entre 100 y 250 pesos antes del tratado Utrecht y entre 50 y 125 pesos luego de 1713 , independiente del sexo y el color (ver gráfico $\mathrm{N}^{\circ} 1$ ).

83 Para la confección de este gráfico nos fijamos en los precios que aparecían en las cartas de libertad. Hubiese sido deseable realizar esta operación mostrando los registros de negros y mulatos por separado. La diferencia entre ambos esclavos podría, también, explicar la baja incidencia de los negros en la manumisión. Lamentablemente, los datos son muy incompletos. Si bien este ejercicio pudiera tener errores en cuanto a una correlación exacta entre la edad y el precio, lo que nos interesa es destacar la idea de un proceso de avaluación "normal" del esclavo durante el desarrollo de su vida. Exceptuamos, obviamente, a los esclavos mutilados y aquellas transacciones en que la libertad no se pagaba al contado. 
CUADRO N ${ }^{\circ} 11$

SEXO Y EDAD DE LOS ESCLAVOS LIBERADOS POR SUS FAMILIARES EN SANTIAGO DE CHILE

(1698-1750)

\begin{tabular}{|c|c|c|c|c|c|c|c|c|}
\hline \multirow[b]{2}{*}{ Edad } & \multicolumn{3}{|c|}{ 1698-1713 } & \multicolumn{3}{|c|}{ 1713-1750 } & \multicolumn{2}{|c|}{ 1698-1750 } \\
\hline & Hombre & Mujer & Total & Hombre & Mujer & Total & Total & $\%$ \\
\hline 0 a 7 & 2 & 2 & 4 & 2 & 4 & 6 & 10 & 59,0 \\
\hline 8 a 15 & 1 & 1 & 2 & & 2 & 2 & 4 & 23,5 \\
\hline 16 a 30 & & 1 & 1 & & & & 1 & 5,8 \\
\hline 31 a 45 & 1 & & 1 & & 1 & 1 & 2 & 11,7 \\
\hline $460+$ & & & & & & & & \\
\hline Total & & & 8 & & & 9 & 17 & 100 \\
\hline
\end{tabular}

Los únicos tres casos de manumisión de esclavos de 30 o más años se explican, porque fueron los cónyuges quienes los liberaron. El cuadro $\mathrm{N}^{\circ} 11$ demuestra, además, que hay una tendencia a liberar a un mayor número de mujeres. Del total, 11 son mujeres $(64,7 \%)$, mientras que 6 son hombres $(35,3 \%)$. Así, se aseguraba que la descendencia futura naciera disociada de la experiencia de la esclavitud. En cualquiera de los dos casos, el cuadro plantea que la manumisión se juzgó, para los esclavos, como una empresa familiar eminentemente proactiva y jamás recesiva. Interviene una variable económica y, también, afectiva.

En el caso de las manumisiones graciosas, igualmente, se plasma esta misma racionalidad económica por parte de los amos. Algunos historiadores postulan que un alto porcentaje de libertades gratuitas puede ser un índice del carácter paternalista de la esclavitud. Carlos Aguirre menciona que "si admitimos la vieja descripción dulzona de la esclavitud limeña del siglo XIX deberíamos esperar que una alta proporción de los esclavos que accedían a la libertad lo hubieran hecho por una disposición 'graciosa' de sus amos, como expresión precisamente de su particular cariño" 84 . De la misma opinión es Schwartz para el caso de Bahía: "el hecho de que la mitad de las manumisiones sean pagadas por los esclavos o que alguien pague por ellos quiebra la interpretación tradicional que le da a la manumisión brasileña un carácter humanitario" 85 .

No obstante, no es válido hacer esa correlación. Por varias razones se puede interpretar que el pago de la libertad fue una cooptación. Consideramos que una de las estrategias de los esclavos en Santiago de Chile fue intentar comprar su libertad por todos los medios, pues era la única forma de que valiera legalmente. Esto

\footnotetext{
84 Aguirre, op. cit., 215.

85 Schwartz, op cit., 628. La traducción es nuestra.
} 
explica, también, los distintos y constantes esfuerzos de amos y esclavos para bajar su precio por medio de los testamentos.

Es que los esclavos no solo lo fueron de sus amos, sino, también -y esto no ha sido analizado en profundidad por la historiografía sobre la manumisión-, de un complicado entramado jurídico que reglamentó la herencia del patrimonio familiar. De ahí, la preocupación testamentaria de informar cada uno de los bienes -entre ellos los esclavos-, las deudas contraídas y los préstamos y empeños realizados. Una vez ocurrida la muerte, el albacea designado por el difunto procedía a realizar un inventario de sus bienes y su respectiva tasación. Saldadas las deudas con los acreedores se disponía al reparto entre los herederos forzosos. De todos los bienes se hacía una distinción: la dote, el aporte femenino que pertenecía a la mujer y era administrado por el hombre, y las arras, contribución masculina para el nuevo hogar. El crecimiento de ambos bienes se llamó gananciales $^{86}$.

El ordenamiento jurídico indiano no permitió que los sujetos dispusieran discrecionalmente del patrimonio, sino solo de un porcentaje que se llamó quinto de libre disposición ${ }^{87}$. A su muerte, un porcentaje del resto debía recaer en los herederos que tenían el carácter de forzosos. Esta era la legítima, la que iba a los descendientes: hijos, nietos, bisnietos y los que hubieren venido. En caso de no haberlos, el reparto subía a los padres, abuelos y bisabuelos. Si no existía ninguno de ellos, la obligación era por línea lateral: tíos, sobrinos, primos, entre otros. Pero no se repartía por igual, sino que se disponía de una fracción de la legítima para repartirla obligatoriamente entre los familiares cercanos. A esta porción se le llamaba mejora. En resumen, del total del patrimonio se debía separar un quinto de libre disposición. Los 4/5 restantes se repartían de la siguiente manera: 2/3 se dividían igualitariamente entre todos los herederos forzosos como legítima y $1 / 3$ restante se podía emplear como mejora ${ }^{88}$.

Al ser la libertad graciosa una donación -o sea una merma al patrimonio-, debía formar parte del quinto de los bienes de libre disposición. El esclavo, en cuanto bien, debió ajustarse a esta normativa y bregar contra ella para conseguir su manumisión. Esta situación queda lo suficientemente clara en el testamento de Antonia de la Carrera, parda libre, quien el 28 de noviembre de 1755 manifestó su intención de liberar a su mulata Marcela. La cláusula testamentaria es lata y extensa, pero vale la pena su reproducción completa para aclarar este tema:

"en atención a lo mucho que debo a Marcela mulata mi esclava así por su mucha fidelidad amor y voluntad con que me ha servido [...] es mi voluntad dejarla como la dejo libre y horra de toda esclavitud y cautiverio para cuyo efecto aplico el resto

86 Antonio Dougnac R., "Esquema del régimen económico matrimonial en Chile Indiano", en Revista Chilena de Historia del Derecho 2, Santiago, 1975, 165-206.

87 Tercera Partida, Título V, Ley X: "Ningún hombre que hubiere hijos o nietos de suso no puede mandar ni dar, a su muerte, más que la quinta parte de sus bienes".

88 Francisco Javier Lagartos, "La 'mejora' como una forma de corregir el igualitarismo castellano. Comarca de Sahagún, siglo SVIII”, en Estudios Humanísticos. Historia 4, León, 2005, 121-148. 
de los trescientos y cincuenta y dos pesos que me sobran de mi quinto pagado mi funeral con los cuatro cientos pesos que llevo destinados; Por manera que once pesos y cuatro reales que hay de remanente del dicho mi quinto sobran para esta libertad trescientos y sesenta y tres pesos y cinco reales que es el único precio que se le puede dar a la dicha mi esclava y para en el caso que los susodichos o alguno de ellos pusiese reparo en que la dicha esclava está tasada en cuatro cientos pesos en este caso no perdonándole los dichos mis hijos este corto alcance que hace del precio que le pongo al de su tasación en que pudiera valerme de parte de mi tercio que no lo hago por la confianza que de ellos tengo y que es obra pía comunicarle este beneficio a la dicha esclava dejándoles como les dejo íntegro mi tercio para que entre ellos lo repartan no conteniendo en esto que les propongo es mi voluntad para que tenga efecto la dicha libertad que este corto pico que falta a su tasación se saque de el valor de los cuatro cientos pesos que tengo destinados para mi funeral porque esta libertad la confiero con ánimo de no revocarla por codicillo ni por otro instrumento alguno" 89 .

Antonia de la Carrera, en vista de la dificultad que existía de liberar graciosamente a su esclava, quiso devaluarla hasta que su precio cupiera en el quinto de libre disposición. De otra forma, sus herederos, amparados en la rigurosa legislación sobre la herencia patrimonial, habrían intentado revocarla, pues -recordemosse igualaba a una donación. Con la finalidad de evitar un seguro juicio -como el que provocaba la mayoría de las intenciones de libertad de los testamentos-, Carrera estipuló que se sacara dinero de su funeral, en caso de que el precio de su esclava fuera mayor al de 373 pesos y 5 reales en que la dejaba avaluada. Y, más aún, para frenar una eventual ambición póstuma de sus hijos les recordó que su acción tenía el carácter de obra pía.

Por esta razón, el pago de su precio fue el camino más seguro de los esclavos para corroborar su libertad desde el punto de vista legal y evitar futuros litigios. Y esta misma racionalidad operó en los amos a la hora de otorgarla. En el cuadro $\mathrm{N}^{\circ}$ 12 se analiza la interrelación de las variables edad y sexo de los esclavos manumitidos de forma graciosa. Entre 1698 y 1750 el 35,4\% se ubicó en el rango 0 a 7 y el $26,5 \%$ en el de 46 a 60 (ver cuadro $N^{\circ} 12$ ). Ambos son esclavos, cuyas edades están en un periodo de menor avaluación. Un alto porcentaje se ubica en el grupo de 16 a 30 años (20,5\%). Pero algunos de ellos son esclavos: "tuertos de un ojo", "enjutos" o viven lejos, como uno que está preso en una panadería de Lima. Independiente del sexo y el color, los amos liberaron a quienes tuvieron los precios de mercados más baratos.

89 Testamento de Antonia de la Carrera, parda libre. Santiago, 28 de noviembre, 1755, ANCH, ES, volumen 601, f. 115. Las cursivas son nuestras. 
CUADRO N 12

EDAD Y SEXO DE LOS ESCLAVOS MANUMITIDOS DE FORMA GRACIOSA EN SANTIAGO DE CHILE (1698-1750)

\begin{tabular}{|c|c|c|c|c|c|c|c|c|c|c|}
\hline \multirow[b]{2}{*}{ Edad } & \multicolumn{3}{|c|}{$1698-1713$} & \multicolumn{3}{|c|}{ 1713-1750 } & \multicolumn{4}{|c|}{ 1698-1750 } \\
\hline & Hombre & Mujer & Total & Hombre & Mujer & Total & Hombre & Mujer & Total & $\%$ \\
\hline 0 a 7 & 2 & 1 & 3 & 4 & 5 & 9 & 6 & 6 & 12 & 35,4 \\
\hline 8 a 15 & & 2 & 2 & 2 & & 2 & 2 & 2 & 4 & 11,8 \\
\hline 16 a 30 & & & & 1 & & 1 & 1 & & 1 & 2,9 \\
\hline 31 a 45 & 2 & & 2 & 2 & 3 & 5 & 4 & 3 & 7 & 20,5 \\
\hline 46 a 60 & & 2 & 2 & 2 & 5 & 7 & 2 & 7 & 9 & 26,5 \\
\hline 60 ó + & & 1 & 1 & & & & & 1 & 1 & 2,9 \\
\hline Total & & & 10 & & & 24 & 15 & 19 & 34 & \\
\hline No dice & & & 1 & & & 7 & & & 8 & 100 \\
\hline
\end{tabular}

\section{LOS PERIPLOS HACIA LA LIBERTAD EN SANTIAGO: OPORTUNIDADES Y ACCESO}

La conversión de los esclavos y los amos en cifras es un ejercicio estadístico delicado. La variable sexo no es difícil de determinar, pues aparece en el nombre, un dato obligatorio. La categorización de los esclavos por el color o la edad -si bien deben relativizarse, pues están mediadas por el filtro ocular de los diferentes escribanos- no originan, mayormente, una dificultad. El problema se genera, principalmente, cuando tipificamos las libertades en remuneratoria o graciosa. Tras los números y las clasificaciones se van eliminando una serie de factores que influyen dentro del proceso. Muchas veces se mencionan como "gratuitas" o "graciosas", pero, al encontrar más documentos, como el testamento del amo o un juicio en la Real Audiencia, la percepción cambia radicalmente. Porque las categorizaciones estáticas subordinan muchos de los esfuerzos que realizaron los esclavos y, también, el esmero no menor que pusieron los amos. Con todo, y exceptuando los errores en la clasificación, el análisis cuantitativo, a veces frío e inevitablemente distorsionador, nos permitió, por medio de la interrelación de diferentes variables, caracterizar el tipo de esclavos y amos que participó en el proceso y, además, interpretar las motivaciones que tuvieron ambos. Pero debemos, forzosamente, añadir la parte cualitativa.

\section{El esfuerzo individual: la autocompra y el préstamo}

En Santiago, el fenómeno más importante es la conversión de los esclavos en jornaleros. Y esto se debió, principalmente, a la necesidad económica de sus amas viudas. En la Hispanoamérica colonial, la viudez representó una condición legal excepcional para las mujeres. Después de haber gozado o sufrido la protección y/o el control de su padre o esposo, ellas tenían la oportunidad de alcanzar un mayor grado de independencia: administrar los bienes de la familia, disponer 
de ellos y entablar contratos. Jurídicamente, abandonaban su estatus de "incapaces relativas" a las que las relegó el derecho. Ots Capdequí menciona que la muerte del marido "permite a las mujeres disfrutar de plenos derechos civiles" 90 . En tanto, Silvia Arrom postula que dicho estado "marcaba una importante transición a la autonomía"91.

En las sociedades hispanoamericanas la viudez femenina fue un fenómeno bastante extendido. Las causas: un mayor número de mujeres en el total de la población y la diferencia de edad entre los esposos. Los hombres, por lo general, eran mayores que sus cónyuges ${ }^{92}$. De esta manera, existió una mayor probabilidad de que hubiese más viudas que viudos.

En Chile, la frecuencia de la viudez fue mucho mayor por el carácter militar de la sociedad. René Salinas Meza -en su estudio sobre las mujeres en Chile tradicional- menciona que entre un 8 a $16 \%$ de la población femenina adulta era viuda en el siglo XVIII y comienzos del siglo XIX. Según sus datos, el $48 \%$ de las viudas tenían menos de 50 años y una de cada cuatro menos de 40 años ${ }^{93}$. Pero no todas gozaron esa supuesta autonomía. La muerte del esposo implicaba la pérdida de la figura protectora y del sostenedor económico, dejando a muchas en la ruina. "La sobrevivencia por sus propios medios se dificultaba, por lo que no fue extraño que muchas de ellas recurrieran a la beneficencia en busca de protección y ayuda" 94 .

Luisa de la Peña enviudó y tuvo que beneficiarse del trabajo de su esclavo, el mulato Juan Joseph de la Peña. En 1700, su ama declaraba que lo liberaba:

"porque en todo el tiempo que ha estado enferma en cama que a su parecer habrá sido de veinte y cuatro años a esta parte no ha tenido otros efectos de que poderse sustentar sino es de lo que el dicho esclavo ha ganado con su trabajo personal y con ello le ha acudido como buen esclavo desvelándose noche y día en adquirir para socorrerla" ${ }^{95}$.

Pero se la daba "pagando a su albacea trecientos pesos de a ocho reales para pagar los gastos de mi funeral"96. Debía seguir manteniéndola hasta la muerte, porque era su único sustento.

Los esclavos supieron aprovechar las ventajas de su transformación en jornaleros. Fue una oportunidad que significó que pudieran alcanzar su manumisión, aunque con mucho esfuerzo y laboriosidad. Pero su tipo de libertad dependió del número de integrantes de la familia del amo, de la suya propia y de su edad. Juan

90 José María Ots Capdequí, "El sexo como circunstancia modificativa de la capacidad jurídica en nuestra legislación de Indias", en Anuario de Historia del Derecho Español 7, Madrid, 1930, 312.

91 Silvia Arrom, Las mujeres de la ciudad de México, México D.F., Siglo Veintiuno Editores, 1988,145

92 Christine Hünefeldt, "Penas y penitas de las viudas limeñas en el siglo XIX", en Magdalena León y Eugenia Rodríguez (coords.), Propiedad y género en la América Latina del siglo XIX, Bogotá, Pontificia Universidad Javeriana, Universidad Central y Universidad Nacional de Colombia, 2005, 259.

93 René Salinas Meza, "Las otras mujeres: madres solteras, abandonadas y viudas en Chile tradicional" (manuscrito inédito), Santiago, 2008, 24.

94 Ibid., 14

95 Carta de libertad a Juan Joseph de la Peña. Santiago, 14 de junio, 1700, ANCH, ES, volumen 406, f. 227.

96 Idem. 
Joseph aprovechó la soledad del hogar de su ama: no había herederos forzosos ni nadie a quien recurrir para que la ayudasen.

Aquellos más jóvenes, por su alto precio, tuvieron que extremar sus recursos para conseguirla. Su propio ímpetu juvenil fue un acicate. Pero, a veces, podía haber algo de suerte, como le ocurrió a la mulata Ignacia. Su dueña, la monja profesa Nicolasa Zapata de Irarrázabal la había declarado libre en su testamento, "con calidad de que sirviese cuarenta años"97. Quiso la voluntad divina que su ama tuviese urgencias económicas y requiriese de dinero líquido. Se acercó a negociar y la liberó: "porque de presente me ofrece el precio de su valor y me es de utilidad conferirle la libertad puesto que para mis necesidades me es de mayor conveniencia valerme de los dichos trecientos pesos que no de su servicio" "98. ¿Qué hizo para conseguir ese dinero en tan corto lapso? El escribano Manuel de Cabezón nos relató su estrategia: "la dicha libertad le da y otorga por los dichos trecientos pesos que algunos bienhechores han dado de limosna" 99 . La mulata le trocó la mano al destino. No sabemos quiénes fueron esos filántropos. Quizás, contactos sociales que se habría granjeado con sus trabajos en la calle. Pero este caso nos demuestra que con una buena negociación en el momento oportuno, la libertad no era una quimera.

Pero la suerte no fue la norma, sino más bien el esfuerzo y el conflicto. Aquellos esclavos que vieron que su tiempo económico oportuno para su libertad había pasado prefirieron adoptar la estrategia afectiva a largo plazo: ser leal, obediente y así ganarse el cariño de sus amos para optar por una libertad graciosa. Pero, cuando esta donación no llegó, y a falta de ayuda familiar, uno de los caminos y el más recurrente antes de 1713 fue el de conseguir un préstamo. El mulato Pedro Carrera tenía 55 años y temió la posibilidad de morir sin ser libre. Su amo, el cura Joseph García, al momento de ahorrarlo confesaba que tenía en su poder "por mano de intercesores el capitán don Miguel de Carrera setecientos y cincuenta pesos"100. Fue este un hermano de su ex amo.

Los amos y amas ligados a la Iglesia, curas y monjas, nunca otorgaron una libertad graciosa. Ni siquiera aunque los esclavos hubiesen mostrado la mayor fidelidad y realizado trabajos tan celosamente, al punto de mermar su cuerpo. El mulato Francisco Javier, de 44 años, perteneciente al colegio de San Miguel de los jesuitas, debió pagar 400 pesos, a pesar de que "ha servido en todo cuanto se ha mandado y se halla enfermo del continuo trabajo de servir a los padres religiosos"101. Los precios eran tan altos que no bastaba el buen comportamiento.

Sin embargo, los curas ocuparon un importante rol otorgando algunos préstamos a los esclavos. El 25 de agosto de 1700 se presentó doña Catalina Lisperguer, viuda, para liberar a María de Amasa, mulata de 26 años: “por la buena voluntad que le tengo y por los dichos quinientos pesos que me ha dado y pagado por mano

97 Carta de libertad a Ignacia. Santiago, 21 de enero, 1701, ibid., volumen 408, f. 24 vta.

98 Idem.

99 Idem.

100 Carta de libertad a Pedro Carrera.

Santiago, 23 de septiembre, 1699, ibid., volumen 431, f. 304 vta.

101 Carta de libertad a Francisco Javier. Santiago, 1 de agosto, 1699, ibid., volumen 428, f. 313 vta. 
del Muy Reverendo Padre Maestro Fray Ramón de Córdova del orden real de Nuestra Señora de las Mercedes"102.

Un caso extremo de endeudamiento es el de la mulata Tomasa. Su nuevo paradero fue la casa de María de Garay, sobrina de su ama Mariana de Salfate, quien "murió abintestato [sin hacer su testamento] sin dejar herederos legítimos ascendientes ni descendientes por lo cual fue única heredera de todos sus bienes"103. El 13 de septiembre de 1701 conseguía su libertad, a los 35 años, porque "es buena cristiana y ha ofrecido por su libertad ciento y ochenta y cinco pesos de a ocho reales para pagar los gastos del funeral de la dicha su tía"104. Los lazos con su nueva ama no eran tan fuertes y su adjudicación se debió por vericuetos legales hereditarios: su nueva dueña nunca habría esperado tal herencia. Aprovechando esta situación, la mulata creía realizar un buen negocio: cambiaba su libertad por el pago de un entierro y, de paso, satisfacía su alma, sabiendo que haría una buena obra por su antigua propietaria. Pero no tenía el dinero de contado y debió pedir un préstamo a Leonor de Astorga. La transacción quedaba sellada: "recibe la dicha doña María de Garay de la dicha libertad por mano de la dicha Leonor de Astorga los dichos ciento y ochenta y cinco pesos para pagar los gastos de dicho funeral de la dicha su tía"105.

Su historia no finaliza ahí. El mismo 13 de septiembre realizó un nuevo acuerdo para cancelar el funeral que le otorgaría su libertad: tenía que trabajar para Leonor de Astorga, "que por me hacer amistad y buena obra hoy día de la fecha me ha dado y prestado en reales para que consiguiese como con efecto he conseguido mi libertad" 106 . Por lo mismo, Tomasa declaraba: "prometo y me obligo a servirla en su casa en todo aquello que me quisiere mandar y ocupar hasta que con efecto yo le satisfaga y pague los dichos pesos" ${ }^{107}$. Su nueva ama se había comprometido a darle un sueldo anual de 30 pesos y, además, "mi vestuario y el sustento ordinario y bula de la santa cruzada que asimismo me ha de dar y me ha de curar en mis enfermedades si las tuviere" 108 .

Hasta el 5 de octubre, Tomasa Salfate sirvió en la casa de Leonor de Astorga. Ese día canceló los 185 pesos para el funeral de su antigua ama. Ni siquiera alcanzó a cumplir el contrato de un año. ¿Cómo consiguió el dinero, entonces? Otro documento nos revela su estrategia. Esta vez, la mulata, ahora parda libre, le pidió un préstamo a Asencio de Ureta, quien "por le hacer amistad y buena obra le ha dado y prestado en reales para efecto de pagar y satisfacer otra tanta cantidad que la susodicha debía a Leonor de Astorga [...] a quien se los debía por habérselos suplido para efecto de que consiguiere la libertad que al presente está gozando"109. Para pagar este nuevo préstamo, Tomasa Salfate se obligó "a servirle al

\footnotetext{
102 Carta de libertad a María de Amasa. Santiago, 25 de agosto, 1700, ibid., volumen 434, f. 30.

103 Carta de libertad a Tomasa Salfate. Santiago, 13 de septiembre, 1701, ibid., volumen 409, f. 241

104 Idem.

105 Idem.

106 Obligación de Tomasa Salfate. Santiago, 13 de septiembre, 1701, ibid., volumen 409, f. 242. vta.

107 Idem.

108 Idem.

109 Obligación de Tomasa Safate. Santiago, 5 de octubre, 1701, ibid., f. 292 vta.
} 
susodicho en los oficios ordinarios de su casa y en todo lo demás que le fuere mandado [...] a razón de treinta pesos de a ocho reales por año hasta que con efecto haya satisfecho y pagado la sobredicha cantidad esta otorgante al dicho Asencio de Ureta"110.

Tampoco cumplió con este oficio. Le pidió prestado, una vez más, dinero al capitán don Miguel de Carrera e Iturgoyen -el mismo que anteriormente hizo un préstamo al mulato Pedro de Carrera-. Su deuda, con intereses, había subido de 185 a 195 pesos hacia el 29 de mayo de 1702. Llegado el plazo fatal, el prestamista le exigía la devolución, pero "por no hallarse con ella se ha valido de don Lucas Silvestre de Luzuriaga se le supla obligándose la susodicha como por esta escritura se obliga a servirle en los oficios comunes de su casa [...] por cantidad en cada un año a razón de treinta pesos"111.

No sabemos el destino de Tomasa Salfate. El Archivo Nacional -como en tantas otras ocasiones- ha querido esconder el final de esta historia. No obstante, algunos de sus documentos nos mostraron lo suficiente como para formarnos una idea, extrema digámoslo, de las dificultades que tenían los mulatos para conseguir su libertad. Todo comenzó con el azar: su ama no testó y fue a dar a casa de la sobrina, una mujer que no habría tenido interés en ella. Y ofreció pagar el funeral a cambio de ser libre. En dos años, cinco préstamos distintos, tres asientos en diferentes casas y todo para cancelar la misma deuda.

El hecho de que un esclavo cancelara, no obstante, no debemos interpretarlo como una imposición absoluta. Era una estrategia válida y que daba muchos resultados. También, lo era endeudarse para conseguir sus objetivos. Ellos lo quisieron así: ocuparon sus contactos sociales y consiguieron el dinero. Era, de todos modos, la manera más inteligente y racional de actuar. Difícil era que un amo los dejara partir sin obtener el dinero de una inversión que, entre 1698 y 1713, era grande. No pagar significaba ir a la cárcel pública. Trabajar en una casa era desarrollar los oficios de toda una vida. Por lo menos, ya eran libres, y si no lo disfrutaban ellos, podrían hacerlo sus hijos.

\section{Liberación familiar: pagando libertades ajenas y la propia}

A pesar del esfuerzo individual para pagar su precio o conseguir un préstamo, la familia de los esclavos fue el núcleo principal desde el cual se concretó la libertad. Porque las libertades en Santiago fueron, principalmente, una empresa familiar. El caso de la familia Orta es una muestra de cómo los esclavos manipularon las variables de su contexto social para determinar la conveniencia de su propia libertad, gastaron su dinero de forma racional y conocieron el entrampamiento jurídico hereditario.

María de Orta era hija de una negra llamada Isabel. Natural de Buenos Aires, ingresó -junto con sus hijos Luis, Isabel, María, Elena y Francisca-, a formar parte

110 Idem

111 Obligación de Tomasa Salfate. Santiago, 29 de mayo, 1702, ibid., volumen 410, foja 165. 
de la dote que aportó Agustina Venegas a su matrimonio con el capitán Luis de Orta. Durante sus años en la casa de su dueña, la progenie aumentó: a sus cinco hijos se sumaron Asencio y Manuela. Por derecho hereditario, los primeros pertenecían exclusivamente a la ama. No así estos dos últimos que fueron parte de los gananciales. Su ama enviudó y, ante las necesidades, tuvo que comenzar a vender sus bienes, pues su único hijo, el heredero forzoso Luis de Orta, no supo administrar el patrimonio familiar. En su codicilo mencionaba que hizo: "venta de dos casas que la otorgante poseía en la traza de esta ciudad [...] y asimismo en virtud de poder de esta otorgante el dicho su hijo vendió una chácara que la otorgante poseía en el pago de Renca"112.

Mientras el ama lamentaba el decrecimiento de su patrimonio inmueble, el número de los bienes muebles comenzaba a crecer de forma vertiginosa. Paulatinamente, la familia esclava fue ensanchándose con nuevos integrantes. María hija concibió a Francisca; Elena, a Juana Rita e Isabel, superando los partos de sus hermanas, tuvo más de cuatro hijos. Asimismo, la necesidad económica y la ausencia de parientes consanguíneos en el hogar propiciaron que los lazos entre María de Orta y Agustina de Venegas se estrecharan, generando una relación más horizontal. ¿Cómo evitar que la escasez de dinero efectivo se transformara en una motivación patronal para separar a su descendencia?

Ahora abuela de varios nietos, María de Orta aprovechó la confianza con su "amita" para negociar un buen acuerdo y consiguió una libertad graciosa para su nieta Francisca, de 9 años. El 29 de marzo de 1700, Agustina Venegas confesaba que "por haberla criado y ser nacida en su casa hija de María [hija] mulata su esclava [...] le da carta de libertad y ahorro para que después de mis días goce de la dicha libertad"113. Solo se haría efectiva a la muerte del ama. Pero la esclava prefirió endosar el cariño que la hacía merecedora de una libertad para asegurar que su pequeña nieta no tuviera más esclavos. El ejemplo de sus hijas -y el suyo propio- la habrían animado a precaver y asegurar la libertad de su descendencia.

María de Orta continuó estrechando lazos y se acercó, nuevamente, a conversar con su ama en busca de nuevas concesiones. Ya tenía experiencia y sabía cómo hacerlo. El 16 de junio de 1700, ante un escribano, su ama la liberaba a los 50 años, "porque le ha asistido con mucha voluntad queriéndole recuperar la que le ha tenido otorgada"114. Es más, para mayor seguridad jurídica, Agustina de Venegas pedía que esta donación

"nadie se lo estorbe ni mis hijos ni herederos [...] porque en caso que ellos quieran ponerle pleito a la dicha libertad embarazo o condición por razón de su legítima no lo puedan hacer porque [...] es su voluntad que del quinto de sus bienes sean enterados sus herederos para que no haya contradicción a esta libertad"115.

\footnotetext{
112 Codicilio de Agustina Venegas. Santiago, 26 de noviembre, 1709, ibid., volumen 467, f. 396 vta.

113 Carta de libertad a Francisca. Santiago, 29 de marzo, 1700, ibid., volumen 385, f. 131 vta.

114 Carta de libertad a María de Orta. Santiago, 16 de junio, 1700, ibid., volumen 385, f. 213.

115 Idem.
} 
Esta vez, Orta consiguió más que la anterior: su libertad era inmediata. Unida a la de su nieta, la merma patrimonial sumaba, a lo más, 300 pesos que -como insinuaba su ama- habrían cabido, perfectamente, en el quinto de libre disposición.

Una vez libre, María de Orta decidió salir de la casa para ponerse a trabajar. Ni sus cinco décadas a cuestas aplacaron su ímpetu: habría estado empecinada en conferirle un nuevo rumbo a su vida y emprendió la ofensiva para que toda su familia disfrutara de su mismo estatus. Premunida de su experiencia, sus años en el servicio la capacitaron para ejercer diversas tareas domésticas. Regularmente visitaba la capilla de la Piedad y sus contactos con la sociedad de Santiago fueron diversos. Entre empeños, préstamos y deudas fue configurando una red socioeconómica que iba desde un platero hasta don Miguel Antonio y doña Ana Calderón ${ }^{116}$. Al parecer, así como la necesidad tuvo cara de hereje, también mantuvo los ojos ciegos a las consideraciones raciales cuando fue preciso rentabilizar los bienes. Pero, para sus propósitos, lo más importante fue que consiguió la manumisión de otra de sus nietas. En 1705, Agustina de Venegas confería la libertad a Juana Rita, mulatilla de 5 años:

"criada y nacida en mi casa hija de Helena mulata mi esclava perteneciente a mi dote de los esclavos que llevé cuando contraje matrimonio con el dicho mi marido difunto y hallarme gratificada de los buenos y leales servicios de la dicha Elena mulata como asimismo de María Venegas [sic] parda libre abuela materna de la dicha Juana Rita quien de mucho tiempo a esta parte me está contribuyendo con dinero y todo lo demás necesario para el socorro y alivio de mis necesidades y alimentándome con los mantenimientos ordinarios para mi sustentación beneficios todos que me obligan a la remuneración y recompensa" ${ }^{117}$.

¿Hasta qué punto fueron "graciosas" las libertades de las nietas, Francisca y Juana Rita? En las cartas de libertad se mencionan como donaciones, pero por otros documentos nos enteramos de que María de Orta mantenía económicamente a su ama, alimentándola y ayudándola en sus variadas necesidades. Sin embargo, tantas libertades de ese tipo comenzaron a preocupar a Luis Orta, el único heredero, quien habría visto con recelo las disposiciones que estaba tomando su madre. Bajo su mentalidad económica, ella estaba desperdigando y malbaratando bienes que le correspondían por sucesión forzosa. Sus alegatos surtieron efecto y obligaron a Agustina de Venegas a consentir con su hijo el permiso de todas las libertades futuras e informar de sus últimos movimientos económicos. Así lo hizo el 26 de noviembre de 1709. En su codicilo, declaraba que por 300 pesos y "del consentimiento de el dicho su hijo esta otorgante confirió libertad a María mulata su esclava hija de María [de Orta]"118. También, manifestó su opción de liberar a Manuela con "condición de que diere y pagase al dicho su hijo otros trescientos

116 Testamento de María de Orta. Santiago, febrero, 1713, ibid., volumen 505, f. 55 vta.

117 Carta de libertad a Juana Rita. Santiago, 1705, ibid, volumen 464, f. 392. Las cursivas son nuestras.

118 ibid., volumen 467, f. 396 vta. 
pesos por precio de su libertad y por esta cuenta ha empezado a pagar"119. Y culminaba: "todas las dichas cantidades tiene recibidas el dicho su hijo y se las ha dado por cuenta de su legítima necesaria, futura y forzosa sucesión"120.

Agustina de Venegas cumplía con sus deberes hereditarios para con su hijo y, también, con la fidelidad y el dinero que le entregaba María de Orta. Y aprovechó la misma ocasión para destinar el quinto de sus bienes de libre disposición. En el protocolo disponía que ese porcentaje "se aplique para la libertad de los hijos de las dichas Elena e Isabel y cuanto importare el dicho remanente tanto menos paguen por su valor los dichos esclavos para conseguir su libertad"121. Y continuaba: "mando que después de mi fallecimiento las dichas Isabel y Elena tengan un año para buscar el dinero con que queda gravada su libertad y que en este año no les obliguen a servir" ${ }^{22}$. El ama quiso ocupar el espacio que le otorgaba el régimen hereditario indiano para las libertades graciosas de los numerosos nietos de María de Orta -eran más de 12- y dejó estipulado que Isabel y Elena dispusieran de un año de trabajo a jornal, libres, para reunir el precio de sus libertades.

La eventual muerte de Agustina de Venegas causó preocupación en María de Orta, quien ya tenía un sitio y una vivienda donde se asentó con su familia recientemente liberta. No habría dudado de la palabra de su ama. Sí, de la ambición de su hijo, quien habría podido revocar en un juicio hereditario las libertades "donadas" que consiguió con anterioridad para ella y sus nietas: Juana Rita y Francisca. La instancia legal era engorrosa y, también, habría distraído los esfuerzos de su propósito: liberar a la mayor cantidad de familiares. Había que evitarlo. Por lo mismo, decidió esforzarse para conseguir más dinero y comprar esas libertades. En febrero de 1713, trece años después de conseguir su manumisión, la mulata, ahora parda libre, mencionaba en su testamento:

"Ítem. Declaro que fui esclava de doña Agustina Benegas, la cual por la lealtad y amor con que la serví me otorgó la libertad y desde el día de mi otorgamiento hasta el día de hoy le he estado socorriendo en sus necesidades dándole parte de mi vestuario y alimentos cotidianos en que tengo gastados muchos pesos que pasarán de mil y ochocientos, y asimismo cien pesos en reales para dar al maestro de campo don Luis de Orta su hijo en cuya correspondencia la dicha mi ama ha conferido la libertad a algunos de mis hijos y nietos y nietas decláralo así para conste y para que se sepa que las libertades que a los susodichos ha otorgado han sido remuneratorias y no totalmente graciosas" 123 .

Desde los 50 hasta los 63 años, durante 13 años de vida de liberta, María de Orta reunió 1.900 pesos para liberar a gran parte de su numerosa familia. Y si bien no contamos con más documentos para conocer el final de esta historia, este caso demuestra que las estrategias temporales que usaron los esclavos procedieron de un diagnóstico de su realidad para manipularla a su favor. Ella esperó pacientemente a

\footnotetext{
119 Idem.

120 Idem. Las cursivas son nuestras.

121 Idem.

122 Idem.

123 Ibid., volumen 505, f. 55 vta. Las cursivas son nuestras.
} 
su devaluación por tiempo para optar por una libertad graciosa y decidió usar el dinero para liberar a sus hijas y nietas. Pospuso la suya propia para beneficiar a su progenie más pequeña e indefensa. Sin embargo, como obtuvo buenos dividendos económicos, optó por comprar las libertades gratuitas y evitar un juicio futuro. De Luis y de Asencio, sus dos hijos varones, no se ocupó. Del último no tenemos rastros, pero sí del primero. Luis aprendió el oficio de tintorero de cordobanes y se casó con Clara de Morales, a quien profesaba un profundo agradecimiento. El 8 de junio de 1741, al momento de declarar a sus herederos universales, alababa a su mujer con estas palabras: "porque todo lo que he adquirido ha sido por medio de la susodicha por haberme dado trescientos pesos para mi libertad" 124 . Pedía a sus hijos que vivan "respetando y venerando a la dicha su madre como es tan de obligación suya"125.

El esfuerzo de María de Orta -y, también, el de su ama- demuestran que el complejo entramado jurídico hereditario fue una barrera que debieron superar los esclavos. No todos los que pertenecían a una misma familia patronal podían optar a liberarse de forma graciosa, pues sus valores no habrían cabido en el quinto de libre disposición. La opción más segura era pagar. Y fue el camino más recurrente, sobre todo, cuando sus cuerpos eran dispendiosos. También, vimos la serie de negociaciones de esta esclava: desde conseguir salir a trabajar hasta convenir con su ama y "amito" las libertades de sus hijas y nietas. Y su estrategia: priorizar la manumisión de las mujeres. Era más urgente para así frenar el nacimiento de más esclavos.

Pero otras libertades no se fraguaron en una atmósfera tan idílica. Por lo general, las negociaciones ocasionaron conflictos y requirieron de la utilización de la legalidad para conseguirla. Este fue el camino escogido por varios esclavos que no lograron un acuerdo en la "ruta institucional" de la manumisión. Y el principal tema de discusión fue el precio. El 13 de febrero de 1734, Catalina de Espínola contaba las peripecias que debieron sobrellevar unos abuelos, pardos libres, que querían liberar a su nieta:

“Al tiempo y cuando nació Laura Isabel hija de María mulata mi esclava y nieta de la dicha Mariana para bautizarla pidió la dicha María, a la dicha Mariana su madre fuese madrina de la dicha su nieta, y que con este motivo la dicha Mariana le había pedido a la otorgante le confiriese la libertad a la dicha su nieta por el precio de cien pesos con la calidad de que al punto se la había de llevar a su casa habiéndosele puesto por su parte a la dicha Mariana Luz la expresada condición"126.

Mariana Luz, parda libre, en cuatro años, no cumplió con su compromiso. Como el silencio otorga, su ama doña Catalina de Espínola creyó roto el acuerdo. Con el objetivo de reponerlo, el abuelo de la cría en disputa, Alberto Leiva, recurrió a la justicia. Su ama insistía que los 100 pesos ya no eran suficientes por la libertad de la mulatilla, pues habían transcurrido cuatro años y "la dicha Laura

\footnotetext{
124 ibid., volumen 635, f. 349 vta.

125 Idem.

126 Carta de libertad a Laura Isabel. Santiago, 13 de febrero, 1734, ibid., volumen 632, f. 115.
} 
Isabel tenía mayor precio y estima y que este le tocaba así por el trabajo y gastos que había impendido en su educación, como por el riesgo y peligro a que había estado expuesta o de otra fatalidad que pudiese haber acontecido"127. La justicia dictaminó que los descargos de Catalina de Espínola no tenían asidero. Por ello, la obligó a presentarse ante el escribano para dar la carta de libertad. Alberto Leiva y Mariana Luz, pardos libres, habían conseguido liberar a su nieta solo pagando los 100 pesos convenidos cuatro años antes. Ya redactado el documento, su abuelo lo asentía: "y le da las gracias a la dicha doña Catalina por el beneficio que ha hecho a la dicha su nieta"128.

Entre la libertad de la familia Orta y la Leiva hay algunas similitudes. Ambas son gestionadas por abuelos y optaron por liberar siempre a las mujeres más pequeñas: por un tema de natalidad y porque podían acceder a un precio menor de mercado. Pero tiene muchas diferencias. Para María de Orta, los canales de comunicación fueron más expeditos y los años de servicio en la casa la hicieron acreedora de una mayor confianza para negociar. La ayuda constante que brindó a Agustina de Venegas proporcionó fuertes lazos que su ama interpretó como causas de justicia y merecimiento de la libertad. Para los Leiva, la negociación estuvo marcada por el conflicto. Alberto Leiva y Mariana Luz no conocían a Catalina de Espínola: provenían de otro domicilio y el ama de su nieta solo quería aprovechar la situación para sacar ventajas económicas. Ante la terquedad de ella, ambos debieron buscar una salida judicial. Sin embargo, ambas demuestran que la manumisión se juzgó como una empresa familiar proactiva.

\section{Después de 1713: pequeñas opciones}

La apertura de la cordillera al tráfico en 1713 proporcionó a los esclavos mayores oportunidades para negociar. Pero, también, más obstáculos: un mayor número de esclavos en la casa habría generado menores espacios para caber dentro del quinto de los bienes de libre disposición. No obstante lo anterior, algunos no debieron esperar a que ocurriera la viudez, pues la mayor oferta posibilitó que otro tipo de amo participara en el proceso y, además, pudieran reemplazar la mano de obra. El capitán de caballos don Joseph Antonio del Río había comprado a la negrita Inés en 375 pesos en 1730. Necesitaba reunir dinero urgente para que su hermana, Ignacia Benítez, entrara como novicia en el monasterio de la Virgen Santa Clara de la Nueva Fundación. Trató por todos los medios de vender a la negra pero,

"no habiendo habido persona alguna que ofreciere más cantidad por ella que la de trescientos y cincuenta pesos por la decadencia en que han venido los negros esclavos han pedido Pedro y Catalina negros libres padres legítimos de la dicha Inés le otorguen libertad a la dicha su hija por la misma cantidad"129.

127 Idem.

128 Idem.

129 Carta de libertad a Inés. Santiago, 16 de mayo, 1737, ibid., volumen 542, f. 212. Las cursivas son nuestras. 
Y, efectivamente, la consiguieron con el pago.

Al existir un mercado de esclavos más amplio con que podían reemplazar la mano de obra, los esclavos usaron estrategias particulares. La usada por Paulino Vera, mulato libre, para liberar a su esposa fue la más llamativa del periodo. Muchas veces no se tenía el dinero al contado y tampoco se contaba con contactos para pedir un préstamo. De todos modos, se podía comprar la libertad con la entrega de un bien que generara un alto interés. Alonso Pastor y Úrsula Hevia liberaban a María Luisa "en remuneración de los buenos y leales servicios que nos ha hecho y en atención asimismo a habernos dado una negra que yo la dicha doña Úrsula compré a don Matías de Iduarte ayer"130.

Sin embargo, la estrategia más utilizada, después de 1713, fue endosar el capital afectivo -la lealtad y el buen comportamiento- de los padres hacia sus hijos esclavos para que consigan su libertad de forma graciosa, tal como lo efectuó María de Orta, en un principio, con sus nietos y, luego, sus hijas. En 18 de julio de 1733, Lorenzo Pérez daba libertad a María de Mercedes, mulatilla de 3 meses, "hija de Ana mulata mi esclava asimismo la cual libertad le confiero por los buenos y leales servicios que me ha hecho y está haciendo la dicha su madre"131. Cuatro años después, Blasa Díaz, parda libre, liberaba a la negrita Juana Bernarda de seis años, "hija de María Nicolasa su esclava por los buenos y leales servicios de su madre y por que la ha criado y le tiene mucho amor y voluntad"132. En este caso, esclavos y amos obtenían dividendos. Los amos se desligaban de la mantención en salud, vestuario y alimentación. En cambio, los esclavos aseguraban liberar a su descendencia.

También, fue frecuente que los amos otorgasen libertades simultáneas. Hay algunas cartas de libertad que liberan a dos, tres o incluso más esclavos en un mismo documento. El caso más extremo ocurrió un día y un mes no especificado de 1748. Don Pedro Lecaros Barroeta fue albacea y tenedor de bienes de don Gregorio Gaviria. Al morir este último, el primero debía procurar cumplir sus últimas disposiciones testamentarias. Declaraba ante el escribano, en 1748:

"digo que el susodicho antes de su fallecimiento me comunicó la libertad a cinco esclavas que eran de su dominio particular que son Francisca Borja de Fuica, Felipa Fuica, Rosa Gaviria, Domiana Gaviria, María del Carmen Gaviria, por tanto por la presente otorgo que todas las dichas cinco mencionadas a todas juntas y a cada una de ellas de por sí in solidum le concedo la libertad"133.

Cinco mulatas eran declaradas libertas al unísono, de forma inmediata e incondicional y sin cancelar nada. Pero faltaba más, en el mismo documento, el albacea

130 Carta de libertad a María Luisa. Santiago, 5 de junio, 1732, ibid., volumen 631, f. 98 vta. Las cursivas son nuestras.

131 Carta de libertad a María Mercedes. Santiago, 18 de julio, 1733, ibid., volumen 632, f. 10. Las cursivas son nuestras.

132 Carta de libertad a Juana Bernarda. Santiago, 31 de octubre, 1737, ibid., volumen 543, f. 105 vta.

133 Carta de libertad a seis esclavas. Santiago, 1748, ibid., volumen 660, f. 170. 
continuaba: "otra llamada Casimira Fuica declaro que a esta le dio la libertad doña Isabel de Fuica mujer legítima que fue del dicho don Gregorio de Gaviria; y como si es que se otorgó algún instrumento no se sabe y para que de ello conste lo declaro". Pero, en este caso, no había herederos forzosos y ambos cónyuges habían muerto.

\section{CONCLUSIÓN}

La esclavitud en Santiago, entre 1698 y 1750, fue una institución completamente legitimada y ampliamente extendida en diversos sectores de la sociedad. Dos fueron las estrategias que usaron los esclavos para conseguir su libertad: la remuneratoria -el pago de su precio- o la graciosa - una estrategia afectiva a largo plazo-. Pero la decisión sobre la conveniencia de la libertad fue una decisión compleja y fue posible, en mayor grado, para los esclavos más compenetrados con los valores de sus amos y el lenguaje hispano. De ahí el alto número de mulatos y esclavos nacidos en la casa o heredados que la consiguieron. No existió, a priori, una consideración racial por parte de los amos para liberarlos. Más bien, amos y esclavos dejaron que el proceso de manumisión se ajustara a las variables del mercado. En todas sus decisiones impera un factor económico que, en algunos casos, se mezcla con los afectivos.

Comparado con el de otras ciudades de América hispana y portuguesa, el grado de porosidad de la esclavitud en Santiago entre 1698 y 1750 es mínimo y las oportunidades ocurrieron, más recurrentemente, cuando un ama enviudaba. Exigidas económicamente, decidieron rentabilizar a sus esclavos transformándolos en jornaleros para que acudieran con sus pensiones a mantenerlas. Conjuntamente, la ausencia del cónyuge masculino generó mayores posibilidades de modificar una relación otrora jerarquizada a una de mayor horizontalidad y de mutua conveniencia para poder arrancar mayores privilegios. Y se generó, además, un espacio ideal para que el ama percibieran su lado más humano. Ahí, la estructura de la dominación se hacía laxa y flexible. Y aunque estuvieron obligados a solventar económicamente a su ama, lograron, con esfuerzo y ahínco, transformar la coerción en oportunidades y estrategias de liberación. Estos fueron los fenómenos clave por medio de los cuales los esclavos obtuvieron dinero y, también, la posibilidad de negociar.

El régimen hereditario indiano operó como una barrera legal que aportó mayores dificultades a los esclavos para conseguir su manumisión. Al ser la libertad graciosa una donación que mermaba el patrimonio de los amos y sus herederos, su tasación debía forzosamente caber dentro del quinto de libre disposición de los bienes. Por lo mismo, la evaluación de la posibilidad y de la estrategia temporal a usar estuvo influida por una serie de factores: 1) la condición económica del amo y el número de integrantes de la familia patronal; 2) el número de integrantes de la familia esclava, las edades (precio) y sexo de ellas, y su composición: nuclear (dentro de la misma casa) o dispersa (bajo diferentes amos); y 3 ) el precio propio y su edad. Del diagnóstico de esta situación dependió el tipo de manumisión. 
Los esclavos mantuvieron la esperanza de que la libertad pudiera ser factible por buen comportamiento y después de un largo proceso de adecuación de su personalidad a las expectativas del amo (o bien de adaptación natural al sistema que estaban habituados). Pero otros, más activos, con más contactos sociales y medios económicos, no esperaron ese momento preciso y negociaron su propia libertad o la de sus parientes. Y en la medida que los integrantes familiares de los amos se reducían, ellos forzaron y pujaron para conseguir la manumisión remuneratoria. Es decir, se adelantaron a un proceso natural que podía llegar, eventualmente, tras largos años de vida. Así vemos que, para los esclavos, se mezclan una serie de intereses económicos y afectivos y, para los amos, una preocupación por el propio bienestar económico y el de la descendencia al momento de optar por la manumisión.

Este es uno de los aspectos que nos parecen más interesantes en Santiago y que solo se puede apreciar con un análisis cualitativo y el entrecruzamiento de fuentes de diversos tipos. Solo así los documentos logran manifestar esa heterogeneidad de periplos hacia la libertad. Porque la cuantificación se puede realizar en algunas áreas que parecen relativamente seguras: color, sexo y edad. No así en las estrategias, porque, a nuestro parecer, no se pueden establecer clasificaciones rígidas para una realidad más diversa y variopinta. Observamos que muchas de las libertades que aparecen como "graciosas" en las cartas -sobre todo la de los esclavos de 0 a 7 años- se deben al esfuerzo monetario y/o conductual de sus abuelos y padres, cuando le agregamos nuevas fuentes. Para un futuro estudio más acabado es imperioso ensanchar la visión con los testamentos de los amos. Resulta indispensable conocer su estatus socioeconómico para determinar las verdaderas posibilidades que tienen los esclavos de siquiera optar por la libertad. También, saber si pertenecen a la dote, las arras o los gananciales, pues influye fuertemente en la estrategia temporal que pudieron usar y al amo con el cual debían congraciarse.

A pesar de todo, la familia esclava fue fundamental para abreviar el periodo de esclavitud. La ayuda económica y los eventuales lazos de sus integrantes la transformaron en una plataforma clave desde la cual se ideó y concretó el proceso de libertad. Por lo mismo, los esclavos -y los ya libertos- orientaron todos sus esfuerzos a liberar a su descendencia. Mezclando estrategias y endosando su capital afectivo, los mayores -cuando el diagnóstico de su realidad lo imponía así- pospusieron sus libertades para beneficiar a su progenie más pequeña e indefensa. Generalmente, operaron con una racionalidad proactiva: siempre se liberó a los menores, priorizando a las mujeres.

Después de 1713 las cifras muestran un abrupto aumento de las libertades graciosas y una baja de las remuneratorias. ¿Significó, esta situación, una mayor porosidad en el sistema esclavista, asociado a la baja de precios que se produjo después del Tratado de Utrecht? Si tuviésemos cifras concretas del desarrollo del tráfico durante el siglo XVIII, podríamos entrecruzarlos con los datos de la manumisión, para sondear si se trató de un aumento que, no obstante, no varió las proporciones. Es decir, podríamos determinar si las oscilaciones de la oferta se corresponden con las de las libertades. Lamentablemente, un estudio de esas características en Chile aún no existe. 
Sin embargo, la causa de ese crecimiento está más relacionada con la forma de abastecimiento que con la devaluación de los precios en el mercado. Porque consideramos que los esclavos tenían una curva de valoración ascendente que transcurría junto con su propia vida y que oscilaba de acuerdo a su edad e independiente del mercado. Por lo mismo, el establecimiento de un mercado con una oferta menos inestable y, por ende, más sostenida, incentivó que los amos fueran menos reticentes a conceder la libertad después de 1713. En caso de darla de forma gratuita, no se perdía una mayor inversión. Y cuando los esclavos la pagaron, la oferta más constante les permitía reemplazar la mano de obra. Así lo testimonia el hecho de que los amos hombres puedan participar del proceso, puesto que los esclavos más preparados no debieron esperar la viudez. 